\title{
Contribution of ammonium nitrate to aerosol optical depth and direct radiative forcing by aerosols over East Asia
}

\author{
R. S. Park, S. Lee, S.-K. Shin, and C. H. Song \\ School of Environmental Science and Engineering, Gwangju Institute of Science and Technology (GIST), \\ Gwangju 500-712, Republic of Korea
}

Correspondence to: C. H. Song (chsong@ gist.ac.kr)

Received: 7 June 2013 - Published in Atmos. Chem. Phys. Discuss.: 20 July 2013

Revised: 26 November 2013 - Accepted: 19 January 2014 - Published: 27 February 2014

\begin{abstract}
This study focused on the contribution of ammonium nitrate $\left(\mathrm{NH}_{4} \mathrm{NO}_{3}\right)$ to aerosol optical depth (AOD) and direct radiative forcing (DRF) by aerosols over an East Asian domain. In order to evaluate the contribution, chemistrytransport model (CTM)-estimated AOD was combined with satellite-retrieved AOD, utilizing a data assimilation technique, over East Asia for the entire year of 2006. Using the assimilated AOD and CTM-estimated aerosol optical properties, the DRF by aerosols was estimated over East Asia via a radiative transfer model (RTM). Both assimilated AOD and estimated DRF values showed relatively good agreements with AOD and DRF by aerosols from AERONET. Based on these results, the contributions of $\mathrm{NH}_{4} \mathrm{NO}_{3}$ to $\mathrm{AOD}$ and DRF by aerosols ( $\Phi_{\mathrm{AOD}}$ and $\left.\Phi_{\mathrm{DRF}}\right)$ were estimated for the four seasons of 2006 over East Asia. Both $\Phi_{\text {AOD }}$ and $\Phi_{\text {DRF }}$ showed seasonal variations over East Asia within the ranges between $4.7 \%$ (summer) and $31.3 \%$ (winter) and between $4.7 \%$ (summer) and $30.7 \%$ (winter), respectively, under clear-sky conditions, showing annual average contributions of $15.6 \%$ and $15.3 \%$. Under all-sky conditions, $\Phi_{\mathrm{DRF}}$ varied between $3.6 \%$ (summer) and $24.5 \%$ (winter), showing annual average contribution of $12.1 \%$ over East Asia. These annual average contributions of $\mathrm{NH}_{4} \mathrm{NO}_{3}$ to AOD and DRF are almost comparable to the annual average mass fractions of $\mathrm{NH}_{4} \mathrm{NO}_{3}$ in $\mathrm{PM}_{2.5}$ and $\mathrm{PM}_{10}(17.0 \%$ and $14.0 \%$, respectively). $\Phi_{\mathrm{AOD}}$ and $\Phi_{\mathrm{DRF}}$ were even larger in the locations where $\mathrm{NH}_{3}$ and $\mathrm{NO}_{\mathrm{x}}$ emission rates are strong, such as the central East China (CEC) region and Sichuan Basin. For example, under clear-sky conditions, both $\Phi_{\mathrm{AOD}}$ and $\Phi_{\mathrm{DRF}}$ over the CEC region range between $6.9 \%$ (summer) and $47.9 \%$ (winter) and between $6.7 \%$ (summer) and $47.5 \%$ (winter), respectively. Based on this analysis, it was con-
\end{abstract}

cluded that both $\Phi_{\mathrm{AOD}}$ and $\Phi_{\mathrm{DRF}}$ cannot be ignored in East Asian air quality and radiative forcing studies, particularly during winter.

\section{Introduction}

Ammonium nitrate $\left(\mathrm{NH}_{4} \mathrm{NO}_{3}\right)$ is an important particulate constituent that is mainly produced via reversible heterogeneous reaction of gaseous ammonia $\left(\mathrm{NH}_{3}\right)$ and gaseous nitric acid $\left(\mathrm{HNO}_{3}\right.$ ) (i.e., $\mathrm{NH}_{3}(\mathrm{~g})+\mathrm{HNO}_{3}(\mathrm{~g}) \leftrightarrow \mathrm{NH}_{4} \mathrm{NO}_{3}(\mathrm{p})$ ). Particulate nitrate $\left(\mathrm{NO}_{3}^{-}\right)$can also be produced via condensation of two nighttime radicals $\left(\mathrm{N}_{2} \mathrm{O}_{5}\right.$ and $\left.\mathrm{NO}_{3}\right)$ onto aerosol particles. Particulate nitrate is then associated with ammonium $\left(\mathrm{NH}_{4}^{+}\right)$formed by partitioning of gaseous $\mathrm{NH}_{3}$. In particular, the irreversible $\mathrm{NO}_{3}^{-}$formation via the condensation of $\mathrm{N}_{2} \mathrm{O}_{5}$ (i.e., $\mathrm{N}_{2} \mathrm{O}_{5}(\mathrm{~g})+\mathrm{H}_{2} \mathrm{O}(\mathrm{p}) \rightarrow 2 \mathrm{H}^{+}(\mathrm{p})+2 \mathrm{NO}_{3}^{-}(\mathrm{p})$ ) is very active at cold temperatures. Thus, it is the dominant reaction pathway to the $\mathrm{NH}_{4} \mathrm{NO}_{3}$ production during winter.

Since $\mathrm{NH}_{4} \mathrm{NO}_{3}$ is a volatile species, its formation has been observed at locations where partial pressures or mixing ratios of $\mathrm{NH}_{3}$ and $\mathrm{HNO}_{3}$ are high (i.e., typically urban and/or highly populated areas). For this reason, the $\mathrm{NH}_{4} \mathrm{NO}_{3}$ formation has been investigated over urban or highly polluted areas (e.g., Zheng et al., 2002; Kim et al., 2006), whereas it has been largely neglected in global air quality modeling studies (e.g., van Dorland et al., 1997; Chin et al., 2001; Takemura et al., 2002). In particular, many previous studies have reported that the influence of $\mathrm{NH}_{4} \mathrm{NO}_{3}$ on aerosol optical properties (AOPs) and on direct radiative forcing (DRF) by aerosols is insignificant (e.g., Andreae, 1995; van Dorland et al., 1997; Adams et al., 1999; Ramanathan et al., 2001; Chin et al., 
2001; Jacobson, 2001; Takemura et al., 2002; Conant et al., 2003; Seinfeld et al., 2004; Chung et al., 2010; Zhang et al., 2012a).

In particular, East Asia is highly populated and its industrial and agricultural growth rates are very high. Thus, the mixing ratios of $\mathrm{NH}_{3}$ (emitted mainly from agricultural sector) and $\mathrm{NO}_{\mathrm{x}}$ (emitted mainly from industrial sector; $\mathrm{NO}_{\mathrm{x}}$ is a precursor of $\mathrm{HNO}_{3}$ ) in the gas phase are high in order for the formation of $\mathrm{NH}_{4} \mathrm{NO}_{3}$ to be active. Therefore, in this manuscript, we wish to investigate whether the contribution of $\mathrm{NH}_{4} \mathrm{NO}_{3}$ to AOD and DRF by aerosols ( $\Phi_{\mathrm{AOD}}$ and $\Phi_{\mathrm{DRF}}$ ) over "East Asia" can really be negligible. If the $\mathrm{NH}_{4} \mathrm{NO}_{3}$ formation is active over East Asia, then its contribution to AOD and DRF by aerosols can be of potential significance in this region.

In the above context, we attempted to answer the following important scientific questions in this manuscript: (1) is the formation of $\mathrm{NH}_{4} \mathrm{NO}_{3}$ sufficiently inactive over East Asia (particularly, over China) such that its impacts on AOD and DRF by aerosols can be ignored, despite strong emissions of its gas-phase precursors such as $\mathrm{NH}_{3}$ and $\mathrm{NO}_{\mathrm{x}}$ ? (2) If the $\mathrm{NH}_{4} \mathrm{NO}_{3}$ formation over East Asia cannot be negligible, then how large are the influences of $\mathrm{NH}_{4} \mathrm{NO}_{3}$ formation on AOD and DRF by aerosols expected to be? (3) Is there any seasonal (or temporal) variation in the production of $\mathrm{NH}_{4} \mathrm{NO}_{3}$ over East Asia? (4) Can any characteristic feature be found in the spatial distributions of $\mathrm{NH}_{4} \mathrm{NO}_{3}$ over China (strong source region of $\mathrm{NH}_{3}$ and $\mathrm{NO}_{\mathrm{x}}$ ), as well as over the regions surrounding China, such as the Korean Peninsula, Japan, and Taiwan?

\section{Methods}

In order to estimate the contribution of $\mathrm{NH}_{4} \mathrm{NO}_{3}$ to $\mathrm{AOD}$ and DRF by aerosols in East Asia, meteorological model (MM), chemistry-transport model (CTM), and radiative transfer model (RTM) simulations were carried out sequentially in this study. The Fifth-Generation NCAR/Pennsylvania State Mesoscale Model (MM5) and US EPA Model-3/CMAQ (Community Multiscale Air Quality) v4.5.1 model simulations were first conducted to produce four-dimensional (4D) aerosol composition over an East Asian domain. The accuracy of the CMAQ model simulations was then evaluated by comparison between the particulate composition obtained from the Acid Deposition Monitoring Network in East Asia (EANET) and the China Atmosphere Watch Network (CAWNET) and the CMAQ-calculated particulate composition. After the evaluation, the CMAQ-calculated particulate concentrations were converted into aerosol optical properties with and without the consideration of $\mathrm{NH}_{4} \mathrm{NO}_{3}$ using a conversion algorithm. The CMAQ-estimated aerosol optical depth (AOD) was then assimilated with MODIS-retrieved AOD data in order to further improve the accuracy of the CMAQ-estimated AOD data. Finally, using the assimilated

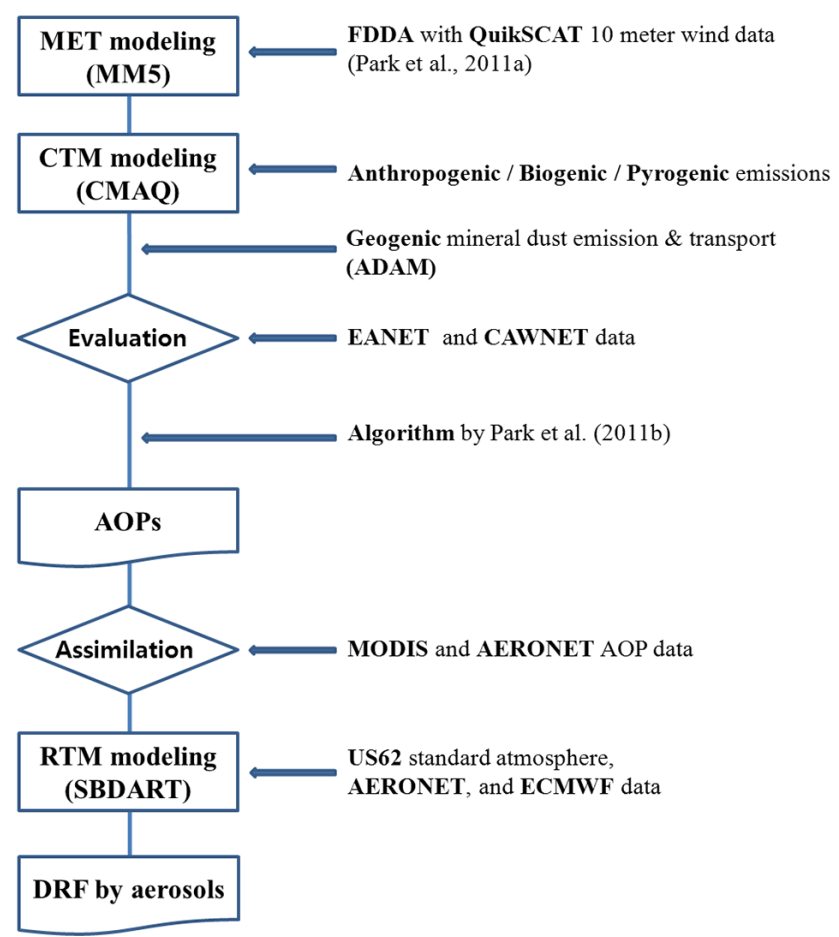

Fig. 1. Flow diagram of the procedures of this study, including (1) meteorological modeling, (2) US EPA Models-3/CMAQ v4.5.1 modeling, (3) ADAM modeling, (4) assimilations of wind data and aerosol optical properties (AOPs), and (5) SBDART radiative transfer modeling.

AOD data, Santa Barbara DISORT Atmospheric Radiative Model (SBDART) simulations were conducted to calculate the DRF by aerosols with and without the consideration of $\mathrm{NH}_{4} \mathrm{NO}_{3}$ concentrations. The flow diagram of the procedures of this study is illustrated in Fig. 1. Detailed descriptions on the procedures of this study are given in the following sections.

\subsection{Chemistry-transport modeling}

First of all, we ran the US EPA CMAQ model in conjunction with MM5 for the entire year of 2006 over an East Asian domain (regarding the domain, refer to Fig. 2). In order to prepare meteorological fields for driving the CMAQ model, $2.5^{\circ} \times 2.5^{\circ}$ NCEP/DOE AMIP-II Reanalysis data (Reanalysis-2) were used for the initial and boundary conditions ( $\mathrm{ICs} / \mathrm{BCs}$ ) for the MM5 simulation. Also, in order to reduce the uncertainty of the MM5 simulation, QuikSCAT $10 \mathrm{~m}$ wind data (collected from the NASA/JPL SeaWinds scatterometer aboard the satellite QuikSCAT) were used for four-dimensional data assimilation (FDDA) (Park et al., 2011a). The spatial resolution for the one-way coupled MM5-CMAQ model simulations was $30 \times 30 \mathrm{~km}^{2}$, with 14- $\sigma$ terrain following vertical layers. AERO4 was employed as the module for the considerations of aerosol 


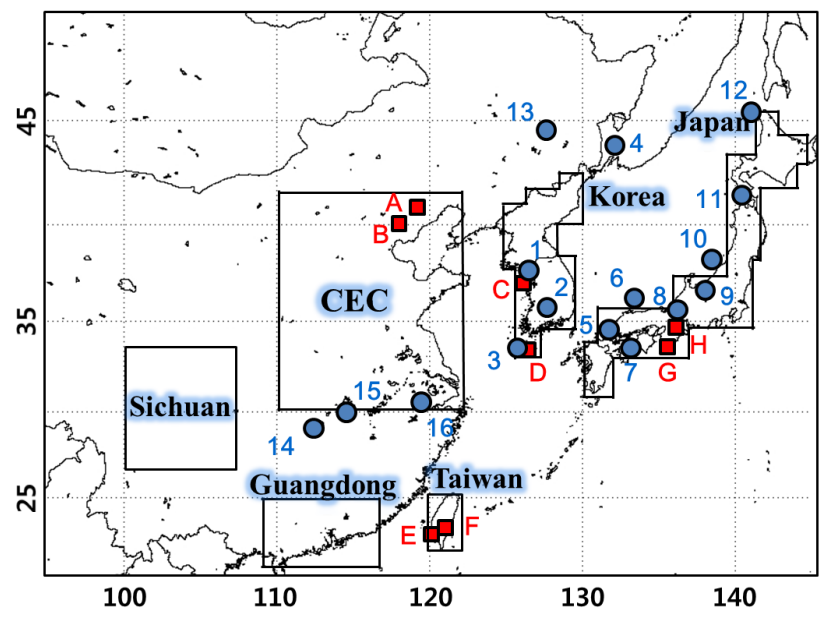

\begin{tabular}{|c|c|c|c|c|c|}
\hline \multicolumn{6}{|l|}{ AERONET sites ( $\square$ ) } \\
\hline A. Xinglong & B. Xianghe & C. & Anmyon & & Gosan \\
\hline E. Chen Kung Univ. & F. Lulin & $\mathrm{G}$. & Shirahame & $\mathrm{H}$. & Osaka \\
\hline \multicolumn{6}{|c|}{ EANET/CAWNET sites (O) } \\
\hline 1. Kanghwa & 2. Imsil & & Cheju & 4. & Primorskaya \\
\hline 5. Banryu & 6. Oki & 7. & Yusuhara & 8. & Ijira \\
\hline 9. Happo & 10. Sado-seli & 11. & Tappi & 12. & Rishin \\
\hline 13. Longfenshan & 14. Taiyangshan & 15. & Jinsha & 16. & LinAn \\
\hline
\end{tabular}

Fig. 2. Model domain of MM5 and CMAQ model simulations and the locations of 8 NASA AERONET sites and 16 EANET/CAWNET sites in the East Asian domain. Also shown are the central East China (CEC) region, the Sichuan Basin, the Guangdong region, Korea, Japan, and Taiwan.

thermodynamic/dynamic processes in the CMAQ model simulations, and SAPRC-99 and Pleim scheme were selected for the gas-phase chemistry and dry deposition, respectively (Pleim et al., 1996; Carter, 2000). In particular, thermodynamics related to the heterogeneous $\mathrm{NH}_{4} \mathrm{NO}_{3}$ formation and decomposition were treated by ISORROPIA model in the AERO4 (Nenes et al., 1998; Fountoukis and Nenes, 2007). Other details on how to run the one-way coupled MM5CMAQ models have been explained in Park et al. (2011b).

For a more accurate chemistry-transport model simulation, the best-available emission inventories were used based on INTEX-B/EDGAR (for China, Mongolia, and Russia), CAPSS (for Korea) and REAS (for Japan) inventories for "anthropogenic" emissions. The EDGAR emission was used only for the consideration of $\mathrm{NH}_{3}$ emission in China, Mongolia, and Russia, since several previous studies have shown that the INTEX-B (or ACE-ASIA) $\mathrm{NH}_{3}$ emissions are possibly overestimated in East Asia (e.g., Kim et al., 2006; Song et al., 2008). The monthly variations of the anthropogenic $\mathrm{NO}_{\mathrm{x}}, \mathrm{SO}_{2}, \mathrm{NH}_{3}$, and NMVOCs emissions were also applied in this study (Han et al., 2009; Park et al., 2011b). In addition, "biogenic" volatile organic compound (BVOC) emissions were calculated by MEGAN (Model of Emissions of Gases and Aerosols from Nature). In order to consider "geogenic" mineral dust emissions and transport, Asian Dust
Aerosol Model (ADAM) simulations were also carried out in East Asia from March to May 2006. The ADAM-estimated concentrations of mineral dust were then simply added to the CMAQ-estimated particulate concentrations based on an assumption that mineral dust particles are not significantly chemically altered during their transboundary transport in East Asia (regarding this issue, refer to Song et al., 2005, 2007a, 2012).

\subsection{EANET/CAWNET data}

EANET was organized as an international effort to enhance a general understanding of the state of acid deposition problems in East Asia; 13 countries in Asia are participating in the EANET activities. Currently, the Asia Center for Air Pollution Research (ACAP) is responsible for managing the EANET (more details are described at http://www.acap.asia/ profile/index4.html). While a total of 51 EANET monitoring sites are located in Asia, the observations from 12 EANET sites in our domain ( 1 site in Russia, 3 sites in Korea, and 8 sites in Japan) were used in this study (regarding the locations of the 12 EANET sites, refer to Fig. 2). Concentrations of 3 particulate species $\left(\mathrm{NO}_{3}^{-}, \mathrm{SO}_{4}^{2-}\right.$ and $\left.\mathrm{NH}_{4}^{+}\right)$ from the 12 EANET sites were mainly used in this study. The three particulate species concentrations were measured using the filter-pack method. This filter-pack measurement has been designed for monitoring the dry deposition in East Asia. However, these 12 EANET sites are all located outside China, although 8 EANET sites have been established inside China (Guanyinqiao, Haifu, Shizhan, Jiwozi, Hongwen, Xiaoping, Xiang Zhou, and Zhuxiandong). Since the filter-pack measurements were not made at the eight Chinese EANET sites, the particulate composition data at those eight sites were not available. At the eight EANET sites in China, ionic concentrations in precipitation (i.e., wet scavenging) were only measured.

Instead of the EANET data, the particulate composition data obtained from CAWNET were used in China. Twenty-four-hour aerosol filter samples were collected at 16 CAWNET sites, which have been managed and operated by the Chinese Meteorological Administration (CMA). However, the particulate composition data from four background CAWNET sites (regarding the locations of the four background CAWNET sites, refer to Fig. 2) were used in this study, because the other sites are all located in and very near megacities and urban areas, and are therefore influenced by local emissions.

The measurements from the EANET/CAWNET have often been used for evaluating the accuracy of chemistrytransport modeling results in East Asia (e.g., Wang et al., 2002; Choi et al., 2009; Jeong et al., 2011). The particulate concentrations of $\mathrm{NO}_{3}^{-}, \mathrm{SO}_{4}^{2-}$, and $\mathrm{NH}_{4}^{+}$obtained from the EANET/CAWNET were again used to evaluate the performance of CMAQ model simulations in this study. The EANET data were obtained from the official EANET 
website at http://www.eanet.asia/product/index.html and the CAWNET data were obtained from Zhang et al. (2012b).

\subsection{CMAQ-estimated aerosol optical properties}

The CMAQ model simulations were carried out in order to produce the 4-D aerosol composition in the domain. Based on the particulate composition calculated via the CMAQ model simulations, AOD $(\tau)$ and single-scattering albedo (SSA; $\omega$ ) were sequentially estimated at a wavelength of $550 \mathrm{~nm}$ (hereafter, "CMAQ-estimated AOD" and "CMAQestimated SSA"). AOD can be theoretically calculated by integrating the aerosol extinction coefficient $\left(\sigma_{\text {ext }}\right)$ with respect to altitude $(z)$ (see Eq. (1), and columnar SSA $(\omega)$ can also be calculated using Eq. (2). In Eqs. (1) and (2), $\sigma_{\text {ext }}$ and $\sigma_{\text {scat }}$ are calculated via Eqs. (3), (4), and (5), as shown below:

$\tau=\int \sigma_{\mathrm{ext}}(z) \cdot \mathrm{d} z$,
$\omega=\frac{\int \sigma_{\mathrm{scat}}(z) \cdot \mathrm{d} z}{\tau}$,
$\sigma_{\mathrm{ext}}=\sigma_{\mathrm{scat}}+\sigma_{\mathrm{abs}}$,

$\sigma_{\text {scat }}\left(\mathrm{Mm}^{-1}\right) \approx 3.0 \times f(\mathrm{RH}) \times\left\{\left[\left(\mathrm{NH}_{4}\right)_{2} \mathrm{SO}_{4}\right]+\left[\mathrm{NH}_{4} \mathrm{NO}_{3}\right]\right\}$
$+\omega_{\mathrm{EC}} \times 10.0 \times[$ elemental_carbon $]+\sum_{i}^{n}\left\{\omega_{\text {dust }, i} \times \beta_{i} \times[\text { dust }]_{i}\right\}$
$+4.0 \times[$ organic_mass $]+1.37 \times f_{\mathrm{ss}}(\mathrm{RH}) \times[$ sea_salt $]$,

$\sigma_{\mathrm{abs}}\left(\mathrm{Mm}^{-1}\right) \approx\left(1-\omega_{\mathrm{EC}}\right) \times 10.0 \times$ [elemental_carbon]

$+\sum_{i}^{n}\left\{\left(1-\omega_{\mathrm{dust}, i}\right) \times \beta_{i} \times\left[\mathrm{dust}_{i}\right\}\right.$,

where $f(\mathrm{RH})$ represents the hygroscopic growth factors of $\left(\mathrm{NH}_{4}\right)_{2} \mathrm{SO}_{4}$ and $\mathrm{NH}_{4} \mathrm{NO}_{3}$, and $f_{\mathrm{ss}}(\mathrm{RH})$ also represents that of sea-salt particles. These factors are a function of relative humidity (RH). In order to calculate CMAQ-estimated AOD and SSA without the consideration of $\mathrm{NH}_{4} \mathrm{NO}_{3}$ in this study, the term " $\mathrm{NH}_{4} \mathrm{NO}_{3}$ " was removed from Eq. (4).

\subsection{Data assimilation}

The AOD data at $550 \mathrm{~nm}$ were also retrieved from the MODIS sensor onboard the Terra satellite (hereafter referred to as "MODIS-retrieved AOD"). Then, the MODIS-retrieved AOD was assimilated, using the CMAQ-estimated AOD in order to produce the most accurate and temporally/spatially continuous sets of the AOD data over East Asia (hereafter, we refer to this product as "assimilated AOD"). This approach is designed to maximize the advantages (and also to minimize the drawbacks) of the CMAQ-estimated and MODISretrieved AOD data sets: the CMAQ-estimated AOD data, spatially and temporally continuous (i.e., four-dimensionally continuous), is not affected by the presence of clouds and high surface albedo, but is believed to be less accurate. In contrast, the MODIS-retrieved AOD data are spatially and temporally discontinuous, depending on the presence of clouds and high surface albedo, but is believed to be more accurate than the CMAQ-estimated AOD. Therefore, we combined the two AOD data sets via a data assimilation technique called optimal interpolation (OI) with a Kalman gain matrix. The expressions for the OI and Kalman gain matrix are shown in Eqs. (6) and (7):

$\tau_{m}^{\prime}=\tau_{m}+\mathbf{K}\left(\tau_{o}-H \tau_{m}\right)$,

$\mathbf{K}=B H^{T}\left(H B H^{T}+O\right)^{-1}$,

where $\tau_{o}$ and $\tau_{m}$ represent the MODIS-retrieved and CMAQestimated AODs, respectively. $H$ denotes the linear operator for interpolation from the model grid to the location of the observations, and $\mathbf{K}$ is the Kalman gain matrix (or Kalman filter). The Kalman gain matrix was calculated by applying seasonally variable free parameters in order to improve the efficiency of the OI in this study (Park et al., 2011b). For the two case studies with and without $\mathrm{NH}_{4} \mathrm{NO}_{3}$, the data assimilation was performed with the same free parameters.

\subsection{AERONET AOD and DRF by aerosols}

In order to confirm the accuracy of the assimilated AOD data, the monthly averaged assimilated AOD values were compared with monthly averaged AERONET AOD values at the wavelength of $550 \mathrm{~nm}$. In addition, the DRF by aerosols was also calculated, and the monthly averaged DRF by aerosols were then compared with the monthly averaged DRF values from eight AERONET sites. The AERONET DRF values were downloaded from the AERONET web site at http://aeronet.gsfc.nasa.gov/. The level 2.0 data set from the AERONET web site was used in this study. The AERONET DRF values by aerosols were calculated using AERONET inversion code that is a corresponding module of radiative forcing model, GAME (Global Atmospheric ModEl) (Dubuisson et al., 1996; Roger et al., 2006). This model performs spectral integration using correlated-k distribution based on line-byline simulations (Scott, 1974). The correlated-k distribution takes into account the interactions between gaseous absorption and multiple scattering with manageable computational time (Garcia et al., 2008); this module is thus believed to accurately account for the molecular scattering and gaseous absorption effects (Garcia et al., 2012).

\subsection{Radiative transfer modeling}

The estimations of the DRF by aerosols with assimilated and model-calculated aerosol optical property data were made via Santa Barbara DISORT Atmospheric Radiative Model (SBDART). This model was developed at the University of California, Santa Barbara, following the method of Ricchiazzi et al. (1998). SBDART is a plane-parallel model that computes the transfer of radiation through 40 layers from Earth's surface to the top of the atmosphere. The SBDART 


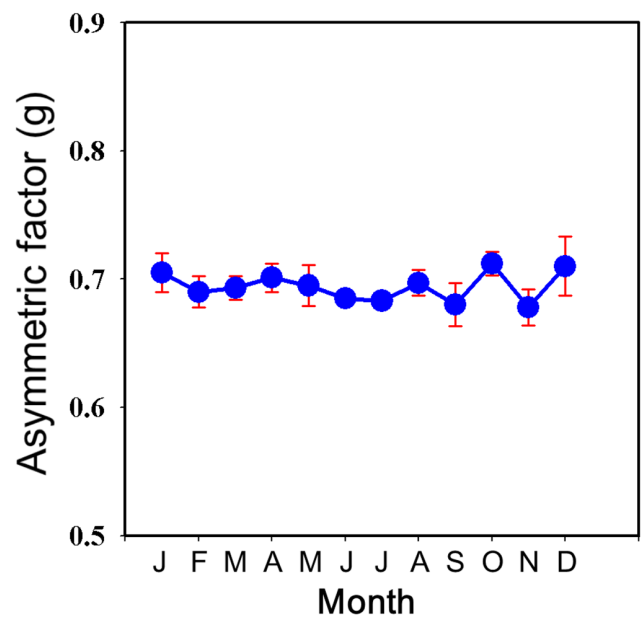

Fig. 3. Monthly averaged asymmetric factors (g) from nine AERONET sites for 2006. The red bars indicate $\pm \sigma$ (standard deviation) of the AERONET asymmetric factor.

has been widely used to date for the analysis of radiative forcing as well as atmospheric energy budget studies (e.g., Xia and Zong, 2009; Ge et al., 2010; Lin et al., 2013; Sena et al., 2013).

The important parameters for the estimations of DRF by aerosols are the AOD, single-scattering albedo (SSA), asymmetry factor $(\mathrm{g})$, surface albedo, and profiles of atmospheric parameters (such as temperature, humidity, ozone, and trace gases). In this study, we assumed the US62 standard atmosphere (US Standard Atmosphere, 1962). Again, the AOD values utilized in this study were improved by the assimilation procedures, and the SSA values calculated from the CMAQ model simulations were evaluated with the values from AERONET and the lidar network ADNET (Asian Dust Network) in East Asia (regarding this work, refer to Park et al., 2011b). The monthly averaged asymmetry factor (g) was retrieved from AERONET and was then used for the SBDART simulations in this study. The mean value of $g$ at the AERONET sites (data from nine sites were available) converged into 0.69 with small standard deviations (see Fig. 3). Therefore, this asymmetric factor of 0.69 was utilized in the SBDART simulations.

The assimilated AOD, CMAQ-estimated SSA, and AERONET-derived asymmetry factor were prepared at a wavelength of $550 \mathrm{~nm}$. In order to consider the spectral dependence of AOD with Ångström model in the SBDART model simulations, the Angström exponent for AOD $(\alpha(\mathrm{AOD}))$ was calculated via Eq. (8) (Chung et al., 2005):

$\alpha(\mathrm{AOD})=$

$\underline{1.9 \tau_{\mathrm{BC}}+1.7 \tau_{\mathrm{OC}+\text { sulfate }+ \text { nitrate }}+1.4 \tau_{\text {seasalt }}+0.6 \tau_{\text {dust }}}$ $\tau_{\text {total }}$

In the study of Chung et al. (2005), the Ångström exponents were calculated without the consideration of ammonium ni- trate, but in this study the contribution of ammonium nitrate to $\alpha$ (AOD) was taken into account. The wavelength dependence of SSA was also considered in this study via a similar approximated method utilized by Chung et al. (2005). In addition, the vertical profiles of aerosols from the SBDART model were used for considering the vertical distribution of aerosols (Valenzuela et al., 2012) and the data of surface albedo over East Asia was obtained from the European Centre for Medium-Range Weather Forecasts (ECMWF).

In addition, cloud information such as cloud optical depth (COD), cloud height, and cloud fraction is necessary in order to calculate the DRF by aerosols under cloudy (all-sky) conditions. Such cloud information in this study was obtained from the MODIS sensor onboard the Terra satellite. The cloud-top height was converted from cloud-top pressure using a state equation, and the cloud bottom height was assumed to be $200 \mathrm{~m}$ above the surface following the assumption of the SCIAMACHY retrieval procedure (regarding this issue, refer to http://www.sciamachy.org/products/ clouds/clouds_IFE_PSD.pdf). The cloud information was then used as input data to the SBDART model simulations under all-sky conditions.

The DRF by aerosols at the top of the atmosphere (TOA), denoted as $\Delta F_{\mathrm{TOA}}$, is defined as the difference between solar irradiances with and without particular particulate species in Eq. (9):

$\Delta F_{\mathrm{TOA}}=-\left(F_{\mathrm{TOA}}^{a}-F_{\mathrm{TOA}}^{0}\right)$,

where $F_{\mathrm{TOA}}^{a}$ and $F_{\mathrm{TOA}}^{0}$ represent the broadband fluxes with and without particular particulate species, respectively. The contributions of $\mathrm{NH}_{4} \mathrm{NO}_{3}$ to DRF $\left(\Phi_{\mathrm{DRF}}\right)$ were estimated from the differences between the DRF values calculated with and without $\mathrm{NH}_{4} \mathrm{NO}_{3}$ in this study. For the comparison with the AERONET DRF values, the SBDART-estimated DRF values were calculated under clear-sky conditions, because the AOD and DRF data from AERONET during cloudy days were screened out. The estimations of DRF by aerosols under clear-sky and all-sky conditions were also made in order to investigate the $\Phi_{\mathrm{DRF}}$ in this study (see Sect. 3.3).

\section{Results and discussions}

\subsection{Evaluation of CMAQ-estimated particulate concentrations}

First, in order to confirm the accuracy of the CMAQestimated particulate concentrations, a comparative analysis between CMAQ-estimated and EANET/CAWNETobserved particulate concentrations was conducted. In Figs. 4, 5, and 6, the CMAQ-estimated particulate concentrations of $\mathrm{NO}_{3}^{-}, \mathrm{SO}_{4}^{2-}$, and $\mathrm{NH}_{4}^{+}$were compared with the EANET/CAWNET-derived particulate concentrations at the 16 EANET/CAWNET sites for 12 months of 2006. In this 


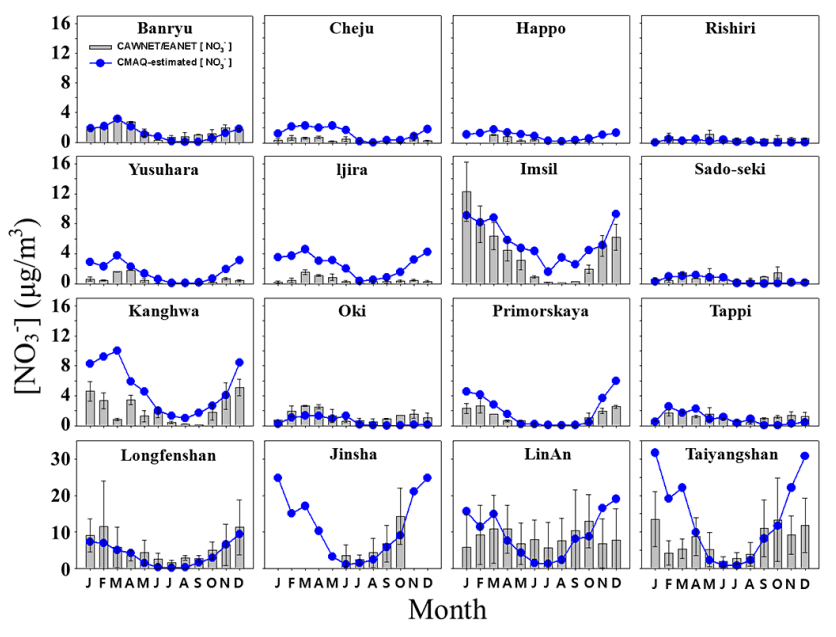

Fig. 4. Comparisons between monthly averaged EANET/CAWNET concentration of $\mathrm{NO}_{3}^{-}$(gray bars) and monthly averaged CMAQ-estimated concentration of $\mathrm{NO}_{3}^{-}$(blue-dotted lines). The comparisons were made at 16 EANET/CAWNET sites. For the EANET particulate composition data, the black bars indicate the ranges of maxima and minima of $\mathrm{NO}_{3}^{-}$concentrations at nine Japanese EANET sites and $\pm \sigma$ (standard deviation) of $\mathrm{NO}_{3}^{-}$concentrations at three Korean EANET sites, respectively. Only maxima and minima of daily and biweekly data were obtained from three Korean and nine Japanese EANET sites, respectively. This is because at the nine Japanese sites only biweekly data were available. In contrast, at the three Korean sites the EANET concentrations were available on daily basis. For the CAWNET particulate composition data, the standard deviations (black bars) were obtained from Zhang et al. (2012b).

study, focus was given to three particulate species, $\mathrm{NO}_{3}^{-}$, $\mathrm{SO}_{4}^{2-}$, and $\mathrm{NH}_{4}^{+}$, because they are the main constituents of atmospheric aerosols in East Asia. Also, other particulate species such as black carbon (BC) and organic aerosols (OAs) were not measured in the EANET activities, partly because these species are not directly related to acid deposition in East Asia.

The CMAQ-estimated concentrations of $\mathrm{NO}_{3}^{-}, \mathrm{SO}_{4}^{2-}$, and $\mathrm{NH}_{4}^{+}$showed relatively good agreements with the EANET/CAWNET $\mathrm{NO}_{3}^{-}, \mathrm{SO}_{4}^{2-}$, and $\mathrm{NH}_{4}^{+}$concentrations (Figs. 4-6). In Fig. 4, the monthly variation of $\mathrm{NO}_{3}^{-}$ showed high values during winter. Such high $\mathrm{NO}_{3}^{-}$concentrations during the winter season are mainly due to the active formation of $\mathrm{NH}_{4} \mathrm{NO}_{3}$ at cold temperatures (i.e., via 2 active heterogeneous reactions in winter: (1) $\mathrm{NH}_{3}(\mathrm{~g})+$ $\mathrm{HNO}_{3}(\mathrm{~g}) \rightarrow \mathrm{NH}_{4} \mathrm{NO}_{3}(\mathrm{p})$ and $(2) \mathrm{N}_{2} \mathrm{O}_{5}(\mathrm{~g})+\mathrm{H}_{2} \mathrm{O}(\mathrm{p}) \rightarrow$ $\left.2 \mathrm{H}^{+}(\mathrm{p})^{+} 2 \mathrm{NO}_{3}^{-}(\mathrm{p})\right)$. In contrast, the monthly variation of $\mathrm{SO}_{4}^{2-}$ showed slightly high values during summer (Fig. 5), partly because of the active formation of $\left(\mathrm{NH}_{4}\right)_{2} \mathrm{SO}_{4}$ at high temperatures. As mentioned in Sect. 1, the sulfate and nitrate formations are active in urban areas and are less active in remote and rural areas. However, the concentrations of $\mathrm{NO}_{3}^{-}$,

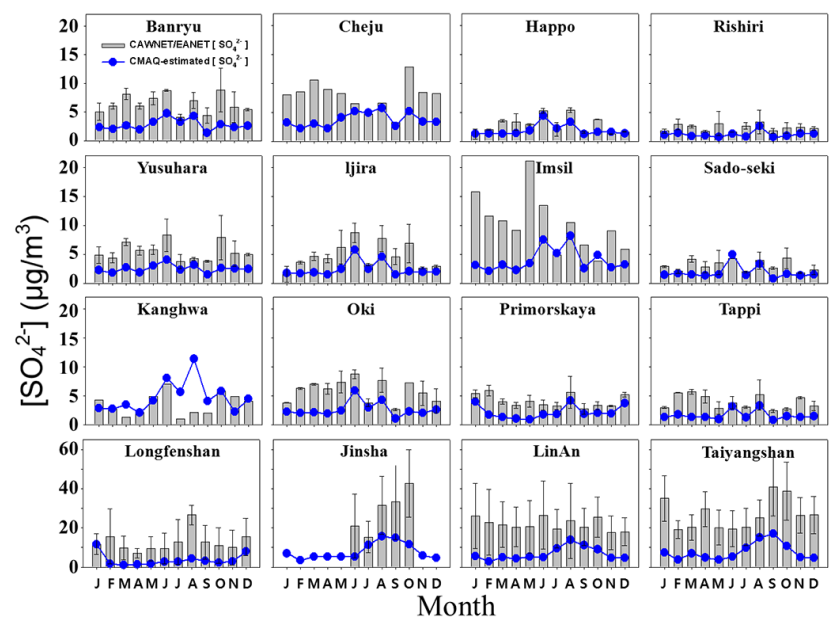

Fig. 5. Same as Fig. 3 but for $\mathrm{SO}_{4}^{2-}$ at 16 EANET/CAWNET sites.

$\mathrm{SO}_{4}^{2-}$, and $\mathrm{NH}_{4}^{+}$at the Cheju, Imsil, and Kanghwa sites (although they are remote and/or rural areas) were comparable to or higher than those at the Banryu site (near urban area) as shown in Figs. 4-6. In particular, the concentrations of $\mathrm{NO}_{3}^{-}, \mathrm{SO}_{4}^{2-}$, and $\mathrm{NH}_{4}^{+}$at such remote and rural sites of EANET during spring, fall, and winter were large. This could be somehow related to the long-range transport of both particulate species and their precursors from China to the Korean EANET sites. In contrast, the concentrations of $\mathrm{NO}_{3}^{-}$, $\mathrm{SO}_{4}^{2-}$, and $\mathrm{NH}_{4}^{+}$at the four CAWNET sites (the bottom rows in Figs. 4-6) were approximately 2 times higher than those at the EANET sites, although the four CAWNET sites are located in the remote and background regions in China.

In the spring, fall, and winter seasons, the wind patterns are typically very favorable for the long-range transport of air pollutants from China to the Korean Peninsula and Japan due to persistent westerly and northwesterly winds in East Asia. In contrast, the surface wind patterns in East Asia are affected by the East Asian monsoon during summer, causing southeasterly winds on the surface during summer. Seasonally averaged surface wind vectors are shown in Fig. 7 using the NCEP/NCAR Reanalysis data set. Based on such seasonal variations of the surface wind patterns in East Asia, transboundary air pollution from China to Korea and Japan could be minimized during summer. Collectively, the highly polluted air masses in China can be more efficiently transported to the Korean Peninsula and the Japanese Archipelago during spring, fall, and winter, and the unexpected high concentrations of $\mathrm{NO}_{3}^{-}, \mathrm{SO}_{4}^{2-}$, and $\mathrm{NH}_{4}^{+}$observed at the three Korean remote and rural EANET sites during spring, fall, and winter can be explained by these seasonal variations of the surface wind patterns in East Asia. In addition, as shown in Fig. 5, the summer $\mathrm{SO}_{4}^{2-}$ peaks at the 12 EANET sites are not particularly distinctive. This is also partly due to the inactive long-distance transport of $\mathrm{SO}_{4}^{2-}$ from China to the Korean Peninsula and Japan in summer. In other words, the 


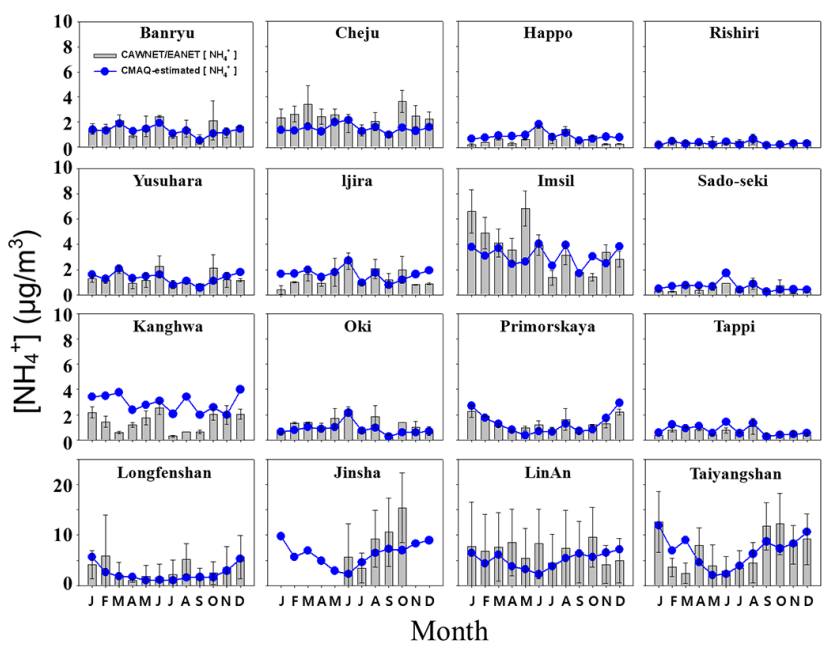

Fig. 6. Same as Fig. 3 but for $\mathrm{NH}_{4}^{+}$at 16 EANET/CAWNET sites.

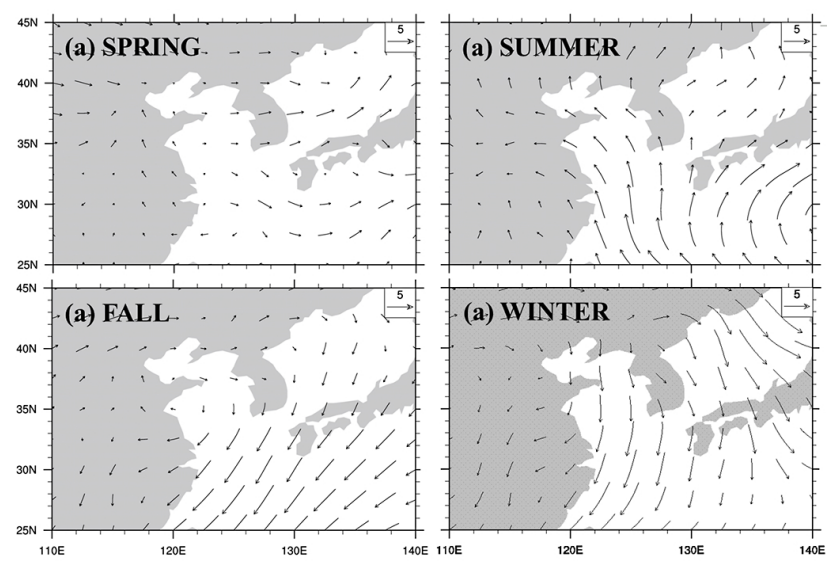

Fig. 7. Seasonally averaged surface wind vectors over East Asia: (a) spring, (b) summer, (c) fall, and (d) winter of 2006. The surface wind data were obtained from the NCEP/NCAR Reanalysis 1 data set and the predicted height corresponds to 0.995 of sigma.

$\mathrm{SO}_{4}^{2-}$ concentrations at the 12 EANET sites in Fig. 5 during spring, fall, and winter are not only photochemically produced, but are also influenced by the long-range transport.

Some statistical analyses between the CMAQ-estimated and EANET/CAWNET-observed particulate $\mathrm{NO}_{3}^{-}, \mathrm{SO}_{4}^{2-}$, and $\mathrm{NH}_{4}^{+}$concentrations were conducted (scatter plot analysis in Fig. 8 and error and bias analysis in Table 1). In Table 1 , the statistical values of R, $\chi^{2}$, RMSE, MNGE, MB, and MNB were analyzed, and the definitions and abbreviations of the statistical variables are presented in the footnote of Table 1. As shown in Fig. 8 and Table $1, \mathrm{NO}_{3}^{-}$ and $\mathrm{NH}_{4}^{+}$show slight positive biases (i.e., CMAQ overestimation), whereas $\mathrm{SO}_{4}^{2-}$ shows negative biases (i.e., CMAQ underprediction). In particular, relatively large root-meansquare errors (RMSEs) with the negative biases in $\mathrm{SO}_{4}^{2-}$ are found compared to those in $\mathrm{NO}_{3}^{-}$and $\mathrm{NH}_{4}^{+}$, as also shown in

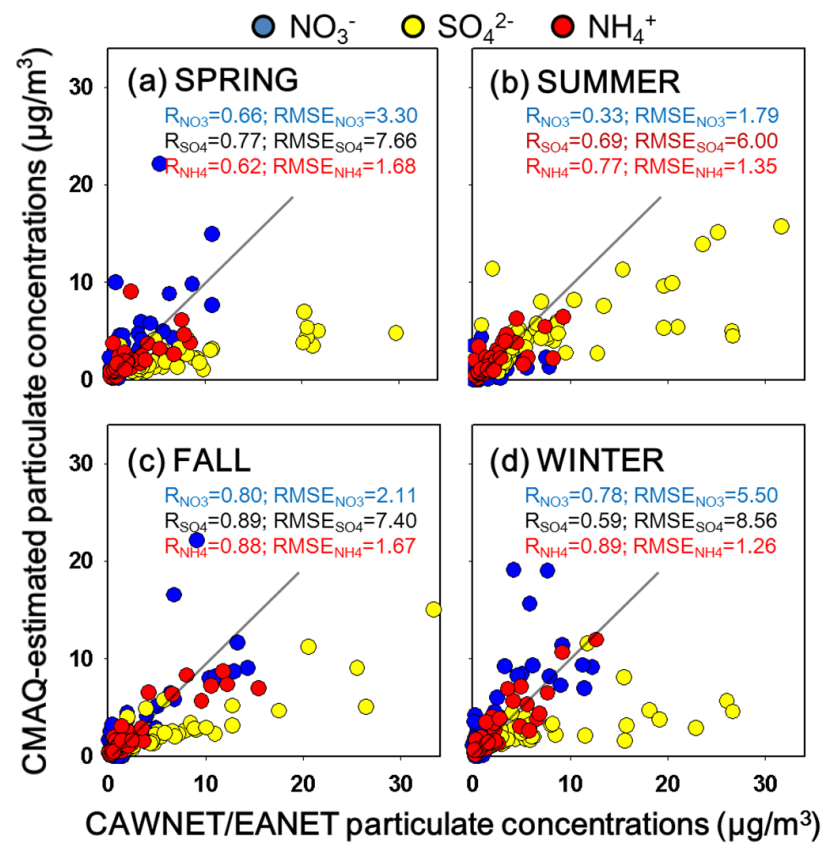

Fig. 8. Scatter plots of CMAQ-estimated and EANET/CAWNETderived particulate concentrations of $\mathrm{NO}_{3}^{-}, \mathrm{SO}_{4}^{2-}$, and $\mathrm{NH}_{4}^{+}$for the four seasons of 2006. Blue, yellow, and red circles indicate concentrations of $\mathrm{NO}_{3}^{-}, \mathrm{SO}_{4}^{2-}$, and $\mathrm{NH}_{4}^{+}$, respectively: (a) spring, (b) summer, (c) fall, and (d) winter.

Figs. 4-6. Such a large underestimation of CMAQ-estimated $\mathrm{SO}_{4}^{2-}$ concentrations, in comparison with $\mathrm{SO}_{4}^{2-}$ concentrations from EANET/CAWNET, can be related to two factors: (1) possible underestimation of $\mathrm{SO}_{2}$ emissions over China (Lu et al., 2010; Smith et al., 2011; Park et al., 2011b) and (2) parameterizations of $\mathrm{SO}_{4}^{2-}$ production rates via $\mathrm{H}_{2} \mathrm{SO}_{4}$ production in the gas phase and heterogeneous $\mathrm{SO}_{2}$ condensation in the CMAQ model (Koch et al., 1999; Song et al., $2003,2007 \mathrm{~b}, 2012)$. The former is related to the uncertainty in the emission inventory over China, while the latter is related to the uncertainty in the atmospheric sulfur chemistry. These large RMSEs with the negative biases in $\mathrm{SO}_{4}^{2-}$ can result in underprediction of CMAQ-estimated AODs compared to the AERONET AOD in Fig. 10. This will be further discussed in Sect. 3.2.

In the similar context, it was also be noted that large parts of the errors and biases mainly occurred at the three Korean EANET sites (Cheju, Imsil, and Kwanghwa) and the four CAWNET sites (Longfenshan, Jinsha, LinAn, and Taiyangshan), as shown in Figs. 4-6. The relatively large errors and biases in the $\mathrm{NO}_{3}^{-}, \mathrm{SO}_{4}^{2-}$, and $\mathrm{NH}_{4}^{+}$concentrations at the three Korean EANET and four CAWNET sites could be partly caused by the uncertainties in the $\mathrm{NO}_{\mathrm{x}}, \mathrm{SO}_{2}$, and $\mathrm{NH}_{3}$ emissions used in this study. As mentioned previously, the INTEX-B/EDGAR, CAPSS, and REAS inventories were used for the anthropogenic $\mathrm{NO}_{\mathrm{x}}, \mathrm{SO}_{2}$, and $\mathrm{NH}_{3}$ emissions over China, Korea, and Japan, respectively. The 
Table 1. Statistical values between $\mathrm{CMAQ}$-estimated and EANET/CAWNET-derived particulate concentrations of $\mathrm{NO}_{3}^{-}, \mathrm{SO}_{4}^{2-}$, and $\mathrm{NH}_{4}^{+}$ for the four seasons of 2006.

\begin{tabular}{|c|c|c|c|c|c|c|c|c|}
\hline Species & Period & $\begin{array}{r}\text { Number } \\
\text { of data } \\
(N)\end{array}$ & $R^{\mathrm{a}}$ & ${\overline{\chi^{2}}}^{b}$ & $\mathrm{RMSE}^{\mathrm{c}}$ & $\begin{array}{r}\mathrm{MNGE}^{\mathrm{d}} \\
(\%)\end{array}$ & $\mathrm{MB}^{\mathrm{e}}$ & $\begin{array}{r}\mathrm{MNB}^{\mathrm{f}} \\
(\%)\end{array}$ \\
\hline \multirow[t]{4}{*}{$\mathrm{NO}_{3}^{-}$} & SPRING & 45 & 0.57 & 1.39 & 3.30 & 129.13 & 1.00 & 99.20 \\
\hline & SUMMER & 48 & 0.33 & 4.40 & 1.79 & 216.99 & -0.33 & 147.91 \\
\hline & FALL & 46 & 0.80 & 16.05 & 2.11 & 143.90 & -0.15 & 71.44 \\
\hline & WINTER & 44 & 0.78 & 2.94 & 5.50 & 372.02 & 2.38 & 339.11 \\
\hline \multirow{4}{*}{$\mathrm{SO}_{4}^{2-}$} & SPRING & 45 & 0.77 & 19.12 & 7.66 & 67.52 & -5.70 & -59.83 \\
\hline & SUMMER & 48 & 0.69 & 8.61 & 6.00 & 56.17 & -3.43 & -11.44 \\
\hline & FALL & 46 & 0.89 & 9.91 & 7.40 & 55.06 & -4.95 & -49.47 \\
\hline & WINTER & 44 & 0.59 & 16.81 & 8.56 & 49.60 & -5.14 & -48.46 \\
\hline \multirow[t]{4}{*}{$\mathrm{NH}_{4}^{+}$} & SPRING & 45 & 0.62 & 0.78 & 1.68 & 56.56 & -0.21 & 23.04 \\
\hline & SUMMER & 48 & 0.77 & 0.91 & 1.35 & 50.01 & -0.31 & 18.96 \\
\hline & FALL & 46 & 0.88 & 0.65 & 1.67 & 42.56 & -0.52 & -1.33 \\
\hline & WINTER & 44 & 0.89 & 0.41 & 1.26 & 54.92 & 0.12 & 33.78 \\
\hline \multicolumn{9}{|c|}{ a Regression coefficient, $R=\frac{N \sum_{1}^{N} M_{i} O_{i}-\sum_{1}{ }^{N} M_{i} \sum_{1}{ }^{N} O_{i}}{\sqrt{N \sum_{1}^{N} M_{i}^{2}-\left(\sum_{1}^{N} M_{i}\right)^{2}} \sqrt{N \sum_{1}^{N} O_{i}^{2}-\left(\sum_{1}^{N} O_{i}\right)^{2}}}$} \\
\hline \multirow{2}{*}{\multicolumn{9}{|c|}{$\begin{array}{l}\text { b normalized chi square, } \overline{\chi^{2}}=\frac{1}{N} \sum_{i}^{N}\left[\frac{\left(O_{i}-M_{i}\right)^{2}}{O_{i}}\right] \\
\text { c root-mean-square error, RMSE }=\sqrt{\frac{1}{N} \sum_{1}^{N}\left(M_{i}-O_{i}\right)^{2}}\end{array}$}} \\
\hline & & & & & & & & \\
\hline \multicolumn{9}{|c|}{$\mathrm{d}$ mean normalized gross error, MNGE $=\frac{1}{N} \sum_{1}^{N}\left(\frac{\left|M_{i}-O_{i}\right|}{O_{i}}\right) \times 100$} \\
\hline
\end{tabular}

large RMSEs and biases derived from the CAWNET and Korean EANET sites could be due to the relatively large uncertainty in the INTEX-B, EDGAR, and CAPSS emissions (again, note that the Korean EANET sites can also be influenced by the uncertainty in the INTEX-B/EDGAR emissions over China via the long-range transport of those particulate species). In contrast, the relatively good correlations between the CMAQ-estimated and EANET-derived particulate concentrations of $\mathrm{NO}_{3}^{-}, \mathrm{SO}_{4}^{2-}$, and $\mathrm{NH}_{4}^{+}$at the eight Japanese EANET sites reflect the relatively high accuracies of $\mathrm{NO}_{\mathrm{x}}, \mathrm{SO}_{2}$, and $\mathrm{NH}_{3}$ emissions from the REAS inventory. Also, the influences of the long-range transport from China would be smaller in Japan than in Korea. Although the CMAQ-estimated particulate concentrations of $\mathrm{NO}_{3}^{-}, \mathrm{SO}_{4}^{2-}$, and $\mathrm{NH}_{4}^{+}$have some errors and biases compared to the EANET/CAWNET data, there are reasonable agreements between the CMAQ-calculated particulate composition and the EANET/CAWNET data, as shown in Figs. 4-6 and 8 and Table 1.

In addition, the mass ratios of the $\mathrm{NH}_{4} \mathrm{NO}_{3}\left(R_{\mathrm{NO}_{3} / \mathrm{PM}_{2.5}}\right.$

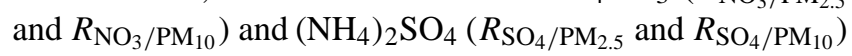
concentrations to $\mathrm{PM}_{2.5}$ and $\mathrm{PM}_{10}$ were calculated from the CMAQ model simulations in East Asia for the entire year of 2006. The annual average values of $R_{\mathrm{NO}_{3} / \mathrm{PM}_{2.5}}$

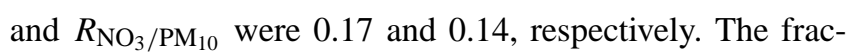
tions are smaller than the values of $R_{\mathrm{SO}_{4} / \mathrm{PM}_{2.5}}(0.25)$

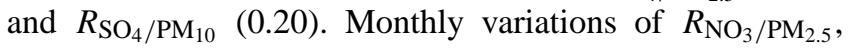
$R_{\mathrm{NO}_{3} / \mathrm{PM}_{10}}, R_{\mathrm{SO}_{4} / \mathrm{PM}_{2.5}}$, and $R_{\mathrm{SO}_{4} / \mathrm{PM}_{10}}$ based on the results of CMAQ model simulations are presented in Fig. 9. As ex-

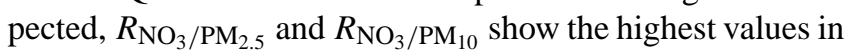
winter, whereas $R_{\mathrm{SO}_{4} / \mathrm{PM}_{2.5}}$ and $R_{\mathrm{SO}_{4} / \mathrm{PM}_{10}}$ show their maxima in summer. This analysis indicates that the mass contributions of $\mathrm{NH}_{4} \mathrm{NO}_{3}$ to particulate matter are almost comparable to those of $\left(\mathrm{NH}_{4}\right)_{2} \mathrm{SO}_{4}$ in East Asia. The $R_{\mathrm{NO}_{3} / \mathrm{PM}_{2.5}}$ and $R_{\mathrm{NO}_{3} / \mathrm{PM}_{10}}$ values (blue lines) are even larger than the $R_{\mathrm{SO}_{4} / \mathrm{PM}_{2.5}}$ and $R_{\mathrm{SO}_{4} / \mathrm{PM}_{10}}$ values (red lines) during winter, as shown in Fig. 9. In terms of the mass fraction, $\mathrm{NH}_{4} \mathrm{NO}_{3}$ cannot be ignored in East Asia, particularly during winter. In this context, the contribution of $\mathrm{NH}_{4} \mathrm{NO}_{3}$ to AOD and DRF in East Asia will be further investigated in Sects. 3.2 and 3.3.

\subsection{Contribution of ammonium nitrate to AOD in East Asia}

The monthly averaged AOD products from AERONET and two assimilated AODs (with and without $\mathrm{NH}_{4} \mathrm{NO}_{3}$ ) were compared in Fig. 10 at eight AERONET sites in order to confirm the accuracy of the assimilated AOD and in order 


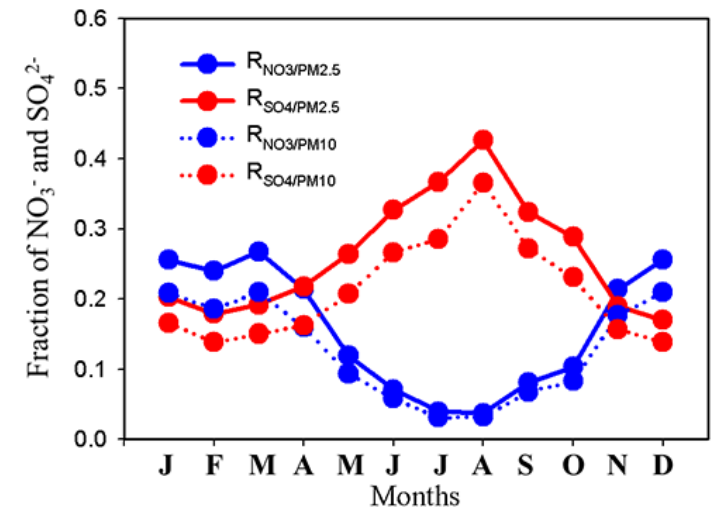

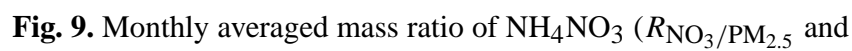
$\left.R_{\mathrm{NO}_{3} / \mathrm{PM}_{10}}\right)$ and $\left(\mathrm{NH}_{4}\right)_{2} \mathrm{SO}_{4}\left(R_{\mathrm{SO}_{4} / \mathrm{PM}_{2.5}}\right.$ and $\left.R_{\mathrm{SO}_{4} / \mathrm{PM}_{10}}\right)$ concentrations to $\mathrm{PM}_{2.5}$ and $\mathrm{PM}_{10}$.

to evaluate the impact of $\mathrm{NH}_{4} \mathrm{NO}_{3}$ on AOD. In this analysis, the AERONET AOD was regarded as the reference value ("ground truth"), since the surface reflectance does not interfere with it and the level 2.0 AERONET data are well calibrated (Holben et al., 1998; Dubovik et al., 2000). The locations of the eight AERONET sites are presented in Fig. 2. As shown in Fig. 2, four pairs of AERONET sites are located in China (near Beijing), Korea, Japan, and Taiwan, respectively. This selection of the AERONET sites was made based on the availability (or scarcity) of data. As shown in Fig. 10, there are relatively good agreements between monthly averaged AERONET AODs (gray bars) and monthly averaged assimilated AODs with $\mathrm{NH}_{4} \mathrm{NO}_{3}$ (blue-dotted lines), showing correlation coefficients (Rs) ranging from 0.71 to 0.91 and RMSEs ranging from 0.08 to 0.21 . In contrast, the degree of agreements decreased when monthly averaged AERONET AODs are compared with monthly averaged assimilated AODs without $\mathrm{NH}_{4} \mathrm{NO}_{3}$ (red-dotted lines). In this case, Rs and RMSEs ranged between 0.45 and 0.91 and between 0.04 and 0.41, respectively. As presented in Fig. 10, the AOD values with $\mathrm{NH}_{4} \mathrm{NO}_{3}$ (blue-dotted lines) are closer to AERONET AOD (gray bars) than the AOD values without $\mathrm{NH}_{4} \mathrm{NO}_{3}$ (red-dotted lines).

It should also be noted here that the monthly averaged assimilated AOD values (blue dotted lines) are in general underestimated compared with the AERONET AOD values, as shown in Fig. 10. These underestimations (or discrepancies) can be affected by several factors: (1) uncertainties in the magnitudes and monthly variations of the emission rates of the gas-phase precursors of particulate species (e.g., Kim et al., 2006; Song et al., 2008; Zheng et al., 2012); (2) underestimation of $\mathrm{SO}_{4}^{2-}$ concentrations, as shown in Figs. 5 and 8; (3) possible underestimation of concentrations of black carbon (BC) and organic aerosols (OAs) (Volkamer et al., 2006; Carlton et al., 2009; Kim et al., 2012); and (4) uncertainties in the one-way coupled MM5-CMAQ model simulations and the composition-to-AOD conversion algorithm (Kinne et al.,

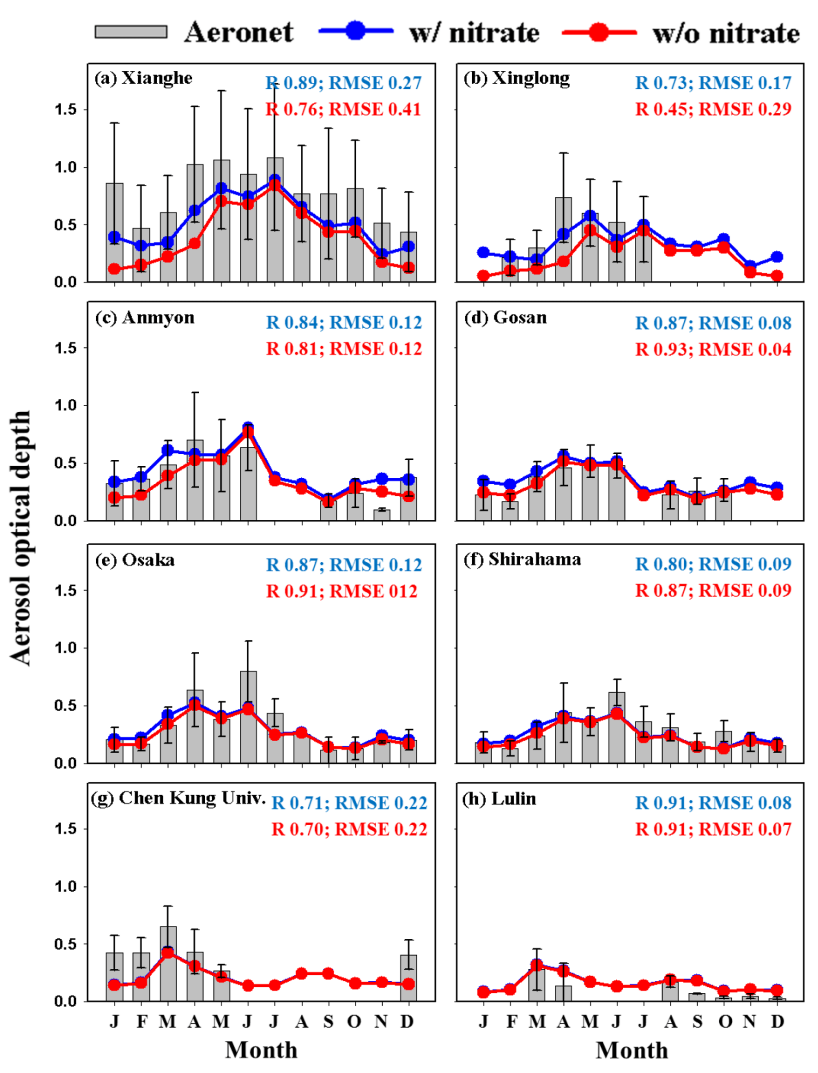

Fig. 10. Comparisons between monthly averaged AERONET AOD (gray bars) and two monthly averaged assimilated AODs with and without $\mathrm{NH}_{4} \mathrm{NO}_{3}$ (blue- and red-dotted lines, respectively). The comparisons were made at eight AERONET sites. $R$ and RMSE represent correlation coefficient and root mean square error, respectively. RMSEs were introduced together with $R$, because $R$ is very sensitive to the number of data and is not very reliable in the case of the number of data being small. The black bars indicate $\pm \sigma$ (standard deviation) calculated from the daily AERONET AOD data. All the comparisons were made under clear-sky conditions.

2003; Zhang et al., 2006; Park et al., 2011b). The degree of underestimation would be more serious if the data assimilation were not conducted with the MODIS-derived AOD values. Here, our intention to conduct the data assimilation is obvious. We would like to correct the underestimated AOD values using the data assimilation and then provide the assimilated AOD values into the SBDART model simulations for a better estimation of DRF by aerosols in East Asia. Here, it needs to be noted that the uncertainty of the MODISretrieved AODs over China was often reported by several studies (e.g., Mi et al., 2007; Wang et al., 2007; Qianshan et al., 2010; Xie et al., 2011). Based on the studies, the errors of the MODIS-retrieved AOD range between 15 and $20 \%$ over China compared with the ground observations, because of the underestimation of MODIS-retrieved surface reflectance and aerosol absorption properties. 


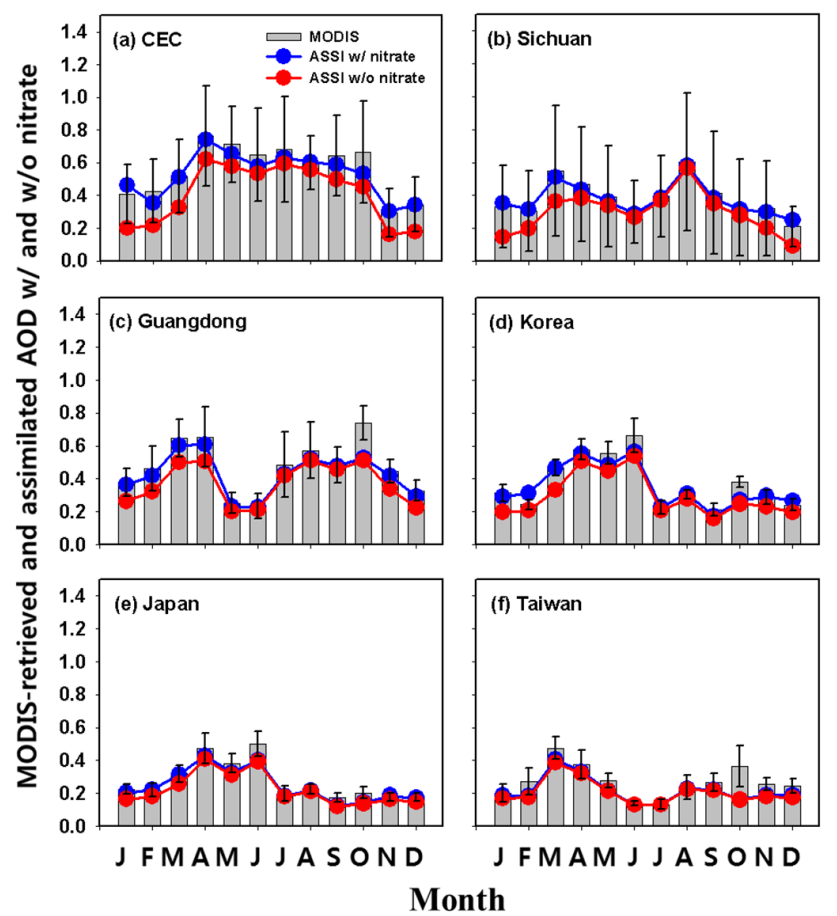

Fig. 11. Comparisons between monthly averaged MODIS-retrieved AODs (gray bars) and monthly averaged assimilated AODs with and without $\mathrm{NH}_{4} \mathrm{NO}_{3}$ (blue- and red-dotted lines, respectively). The comparisons were made over (a) central East China (CEC), (b) Sichuan Basin, (c) Guangdong, (d) Korea, (e) Japan, and (f) Taiwan. The black bars indicate $\pm \sigma$ (standard deviation) of the spatially averaged MODIS-retrieved AOD. All the comparisons were made under clear-sky conditions.

The differences between the monthly averaged AOD values with and without $\mathrm{NH}_{4} \mathrm{NO}_{3}$ vary spatially and seasonally. In Fig. 11, the monthly averaged AOD values with and without $\mathrm{NH}_{4} \mathrm{NO}_{3}$ over six specific regions (central East China (CEC), Sichuan, Guangdong, Korea, Japan, and Taiwan; refer to Fig. 2) were calculated (see blue and red dotted lines), and were then compared with the MODIS-retrieved AOD values (see gray bars in Fig. 11) in order to investigate the regional influences of $\mathrm{NH}_{4} \mathrm{NO}_{3}$ on the AOD values. The differences between the blue and red dotted lines are the largest in the three Chinese regions (CEC, Sichuan, and Guangdong) and are also relatively large in Korea. However, the differences in the other two regions (Japan and Taiwan) are almost negligible. The largest differences in the three Chinese regions are due to more active formation of $\mathrm{NH}_{4} \mathrm{NO}_{3}$ over the Chinese regions than over other regions, because the CEC, Sichuan, and Guangdong regions are highly polluted and emit large amounts of $\mathrm{NO}_{\mathrm{x}}$ and $\mathrm{NH}_{3}$. Especially, $\mathrm{NH}_{4} \mathrm{NO}_{3}$ over the Sichuan region is not efficiently dispersed, because the Sichuan Basin is surrounded by tall mountains. The relatively large differences between the AOD values with and without $\mathrm{NH}_{4} \mathrm{NO}_{3}$ in Korea could also be transferred from

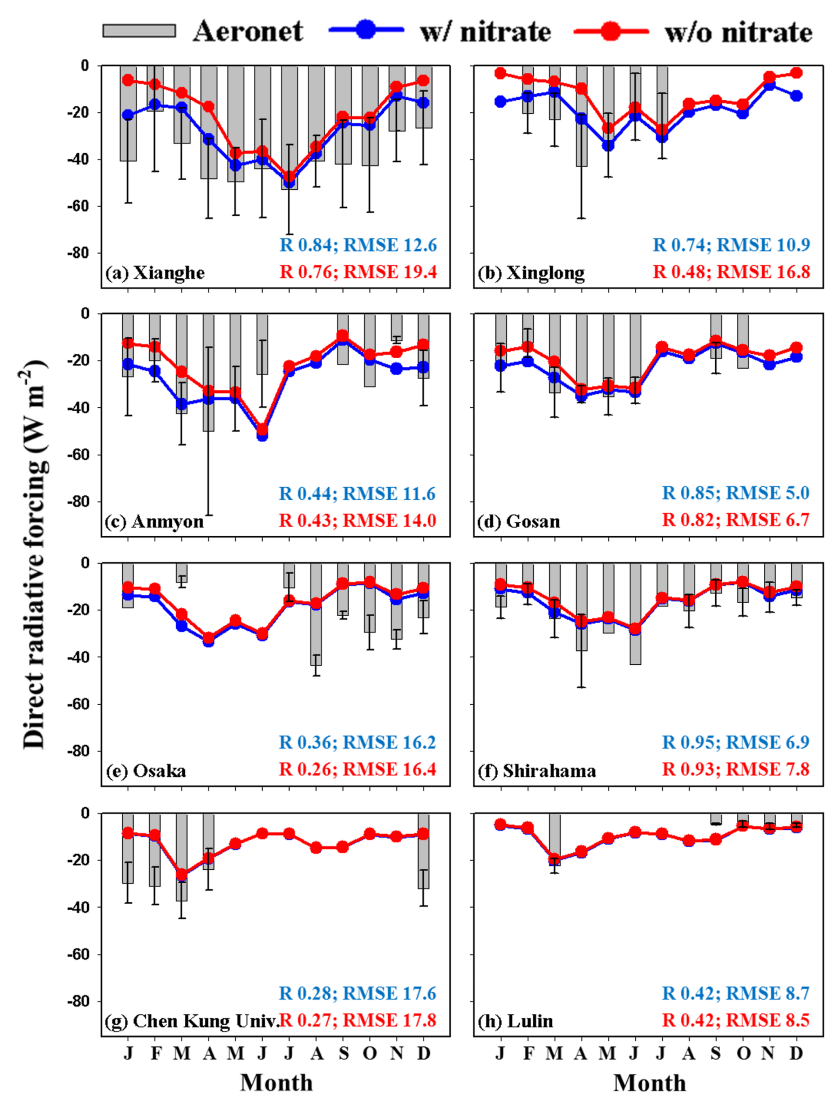

Fig. 12. Same as Fig. 8 but for direct radiative forcing (DRF) by aerosols at eight AERONET sites. Here, the DRF values (blue- and red-dotted lines) were calculated at the top of the atmosphere by the SBDART model. All the comparisons were made under clear-sky conditions.

the CEC region via the long-range transport of particulate species and their precursors due to the proximity between CEC and Korea (refer to Figs. 2 and 7). Also, the differences are larger during cold months (such as December, January, February, and March) in Figs. 10 and 11. This is due to the fact that the equilibrium between gas-phase $\mathrm{NH}_{3} / \mathrm{HNO}_{3}$ and particulate $\mathrm{NH}_{4} \mathrm{NO}_{3}$ tends to shift toward a more active formation of $\mathrm{NH}_{4} \mathrm{NO}_{3}$ with colder temperatures $\left(\mathrm{NH}_{3}(\mathrm{~g})+\right.$ $\left.\mathrm{HNO}_{3}(\mathrm{~g}) \Leftrightarrow \mathrm{NH}_{4} \mathrm{NO}_{3}(\mathrm{p})\right)$. Also, the condensation of $\mathrm{N}_{2} \mathrm{O}_{5}$ radicals onto atmospheric aerosols is particularly active during winter.

In addition to AOD, the CMAQ-estimated SSAs were also calculated with and without the consideration of $\mathrm{NH}_{4} \mathrm{NO}_{3}$ using Eqs. (2)-(5). The annual average SSA values calculated from the CMAQ model simulations show almost negligible differences between the cases with and without the consideration of $\mathrm{NH}_{4} \mathrm{NO}_{3}$ (0.97 and 0.96 , respectively). The differences also show a seasonal variation, ranging from 0.0 (summer) to 0.02 (winter). These CMAQ-estimated SSAs were used for the calculations of the DRF by aerosols in East Asia, which will be discussed in next section (Sect. 3.3). 


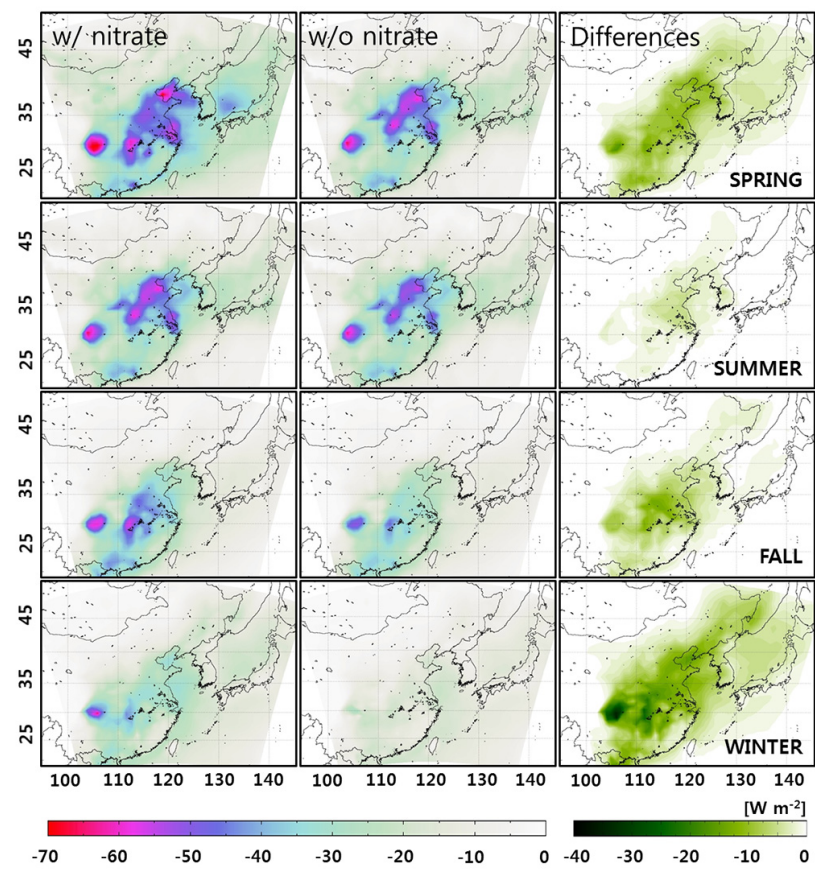

Fig. 13. Direct radiative forcing (DRF) by aerosols at the top of the atmosphere under clear-sky conditions estimated by the SBDART model simulations for the cases with and without $\mathrm{NH}_{4} \mathrm{NO}_{3}$ (the first and the second columns) over East Asia for the four seasons in 2006. Since the DRF values were calculated with total aerosol composition, they showed large negative values (the first column) in spring and summer. These are due to seasonal formation and/or generation of different particulate species such as ammonium sulfate $\left(\left(\mathrm{NH}_{4}\right)_{2} \mathrm{SO}_{4}\right)$ and mineral dust. For example, the formation rates of $\left(\mathrm{NH}_{4}\right)_{2} \mathrm{SO}_{4}$ are maximized in summer and minimized in winter. The third column presents the differences between the first and the second columns. These differences indicate the contributions of $\mathrm{NH}_{4} \mathrm{NO}_{3}$ to DRF by aerosols in East Asia.

\subsection{Contribution of ammonium nitrate to DRF by aerosols in East Asia}

As discussed in the previous section, the monthly averaged DRF by aerosols from AERONET were compared with the monthly averaged DRF estimated from the SBDART at the eight AERONET sites (see Fig. 12). Again, there were relatively good agreements between the DRF from AERONET and the DRF estimated by the SBDART simulations (i.e., gray bars vs. blue-dotted lines in Fig. 12). Also, some differences between the two SBDART-derived DRFs with and without $\mathrm{NH}_{4} \mathrm{NO}_{3}$ were observed (i.e., blue-dotted vs. reddotted lines). The differences are again the largest at the two Chinese AERONET sites and also during the cold months. However, even during the cold months, there are almost no differences in the AOD and DRF values at Japanese and Taiwanese sites, as shown in Figs. 10 and 12. This is due to the fact that the formation of $\mathrm{NH}_{4} \mathrm{NO}_{3}$ is not very active in Japan and Taiwan, because of (1) relatively low levels of $\mathrm{NH}_{3}$ and

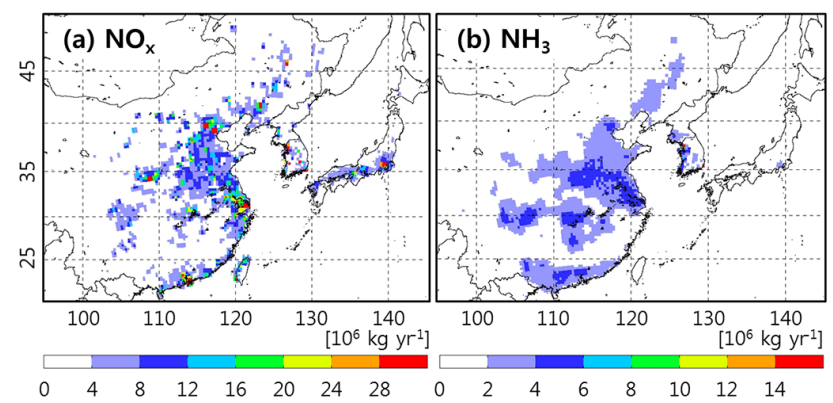

Fig. 14. Spatial distributions of $\mathrm{NH}_{3}$ and $\mathrm{NO}_{\mathrm{x}}$ emissions over East Asia for 2006.

$\mathrm{NO}_{\mathrm{x}}$ and (2) relatively warm temperatures over those locations. This is also shown in Figs. 13 and 14.

Based on the analysis shown in Fig. 12, two-dimensional calculations of DRF by aerosols over the entire East Asian domain were made. Figure 13 shows the spatial distribution of the DRF by aerosols estimated from the SBDART simulations over East Asia for the four seasons of 2006 under clear-sky conditions. As shown in Figs. 10-12, the formation of $\mathrm{NH}_{4} \mathrm{NO}_{3}$ is the most active in winter and spring, and hence the differences in the DRF values (the third column) between the cases with and without $\mathrm{NH}_{4} \mathrm{NO}_{3}$ (the first and second columns in Fig. 13) are the largest in the cold seasons (refer also to the domain-averaged values of the DRF by aerosols for the two cases in Fig. 13).

The differences are particularly large in the regions where $\mathrm{NH}_{3}$ and $\mathrm{NO}_{\mathrm{x}}$ emission rates are strong over the CEC region and the Sichuan Basin. The strong $\mathrm{NH}_{3}$ and $\mathrm{NO}_{\mathrm{x}}$ emissions result in high levels of gas-phase $\mathrm{NH}_{3}$ and $\mathrm{HNO}_{3}$, which again lead to active formation of $\mathrm{NH}_{4} \mathrm{NO}_{3}$ over these locations. The spatial distributions of the $\mathrm{NH}_{3}$ and $\mathrm{NO}_{\mathrm{x}}$ emissions are shown in Fig. 14. According to Fig. 14, the Guangdong region (including Hong Kong and Guangzhou) is also a strong source of $\mathrm{NH}_{3}$ and $\mathrm{NO}_{\mathrm{x}}$, but the formation of $\mathrm{NH}_{4} \mathrm{NO}_{3}$ is less active over this region than over the Sichuan Basin and the CEC region due to relatively warm temperatures. The differences in the DRF between the cases with and without $\mathrm{NH}_{4} \mathrm{NO}_{3}$ reach $-35 \mathrm{Wm}^{-2}$ over the $\mathrm{CEC}$ region and Sichuan Basin during winter. Therefore, collectively, the impacts of $\mathrm{NH}_{4} \mathrm{NO}_{3}$ on AOD and DRF by aerosols should not be ignored, particularly over East Asia, where both $\mathrm{NH}_{3}$ and $\mathrm{NO}_{\mathrm{x}}$ emission rates are strong.

In addition, it is also noteworthy that there are relatively large uncertainties in the $\mathrm{NH}_{3}$ and $\mathrm{NO}_{\mathrm{x}}$ emissions in East Asia (refer to Kim et al., 2006; Song et al., 2008; Han et al., 2009). As discussed previously, these uncertainties can lead to inaccurate estimation of $\mathrm{NH}_{4} \mathrm{NO}_{3}$ concentrations. Therefore, there is a possibility that the discrepancies shown in Figs. 10-12 can be caused by these uncertainties over East Asia. For a more accurate estimation of $\mathrm{NH}_{4} \mathrm{NO}_{3}$ 


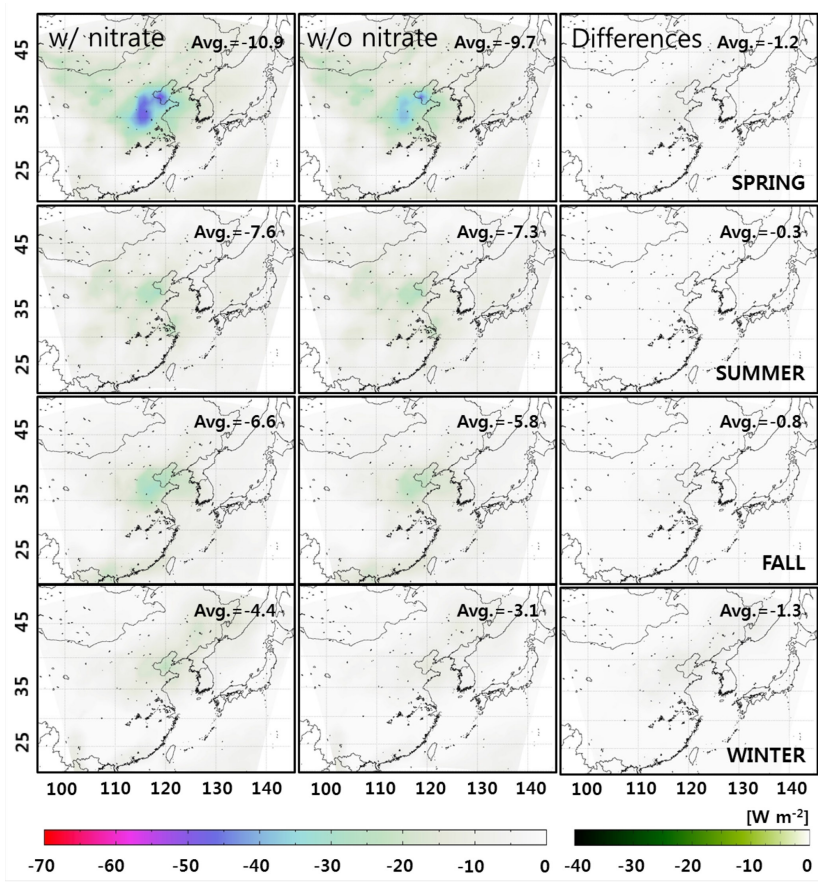

Fig. 15. Same as Fig. 13 but under all-sky conditions.

concentrations in East Asia, improvements in the $\mathrm{NH}_{3}$ and $\mathrm{NO}_{\mathrm{x}}$ emission rates should be made in the future.

The DRF by aerosols under all-sky conditions was also calculated in Fig. 15. The domain-averaged values of the DRF by aerosols under all-sky conditions were smaller than those under clear-sky conditions, because a large fraction of sunlight was scattered by the presence of clouds. In particular, over the Sichuan Basin, the DRF by aerosols under allsky conditions became small, although the DRF by aerosols under clear-sky conditions was large. Such large differences in the DRF by aerosols between under clear-sky and allsky conditions were related to the large annual mean values of COD (cloud optical depth) and cloud fractions over the Sichuan Basin (regarding this issue, refer to Fig. S1).

Both $\Phi_{\mathrm{AOD}}$ and $\Phi_{\mathrm{DRF}}$ are summarized in Table 2 . The contributions were calculated at the eight AERONET sites and over the entire East Asian domain (the numbers in the first parentheses of Table 2 represent domain-averaged values). Both $\Phi_{\mathrm{AOD}}$ and $\Phi_{\mathrm{DRF}}$ over East Asia vary seasonally with the ranges between $4.7 \%$ (summer) and $31.3 \%$ (winter) and between $4.7 \%$ (summer) and $30.7 \%$ (winter), respectively, under clear-sky conditions, showing annual average contributions of $15.6 \%$ and $15.3 \%$. Under all-sky conditions, $\Phi_{\mathrm{DRF}}$ varied between $3.6 \%$ (summer) and $24.5 \%$ (winter), showing annual average contribution of $12.1 \%$ over East Asia. These annual average $\Phi_{\mathrm{AOD}}$ and $\Phi_{\mathrm{DRF}}$ are almost comparable to the annual average mass fractions of $\mathrm{NH}_{4} \mathrm{NO}_{3}$ in $\mathrm{PM}_{2.5}$ and $\mathrm{PM}_{10}$ (17.0\% and $14.0 \%$, respectively). $\Phi_{\mathrm{AOD}}$ and $\Phi_{\mathrm{DRF}}$ become larger in the locations where $\mathrm{NH}_{3}$ and $\mathrm{NO}_{\mathrm{x}}$ emission rates are strong such as in the CEC region and

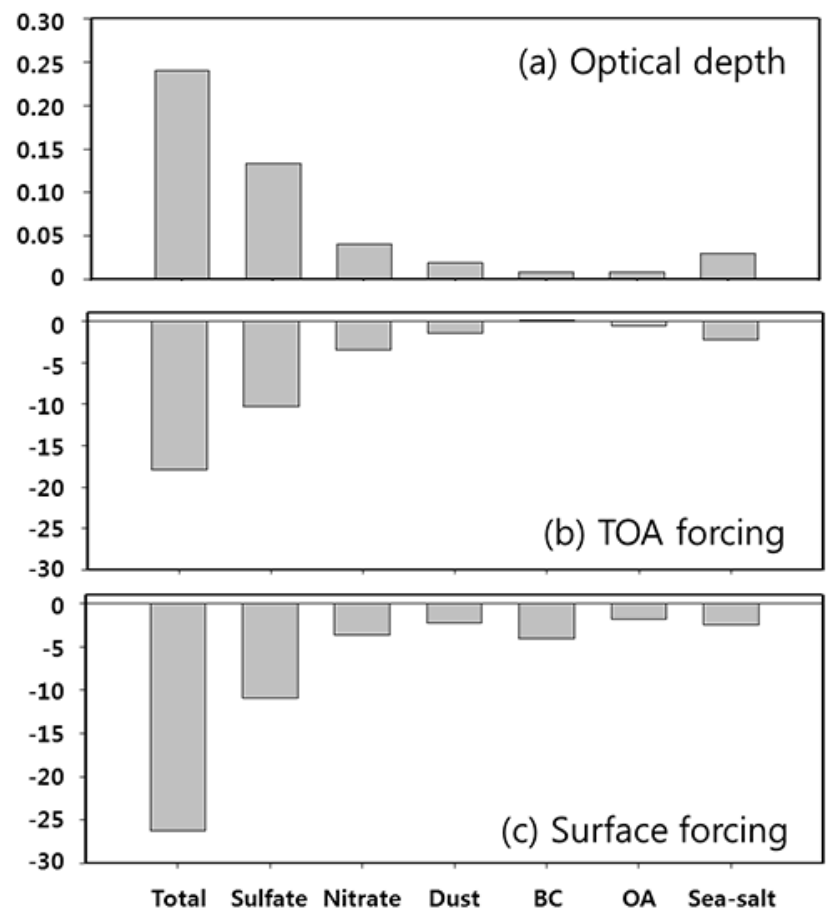

Fig. 16. Contributions of particulate species to (a) optical depth, (b) DRF by aerosols at the top of the atmosphere (TOA), and (c) DRF by aerosols at the surface for the year of 2006 over East Asia. The estimations were made based on the CMAQ model simulations. Therefore, it should be noted that the contributions of sulfate, organic aerosols (OAs), and black carbon (BC) can be underestimated due to possible underestimation of those concentrations in the CMAQ model simulations in East Asia (refer to Figs. 5 and 8 as well as Matsui et al., 2009; Luo et al., 2011; Park et al., 2011b; Kim et al., 2012).

Sichuan Basin. For example, under clear-sky conditions, both $\Phi_{\mathrm{AOD}}$ and $\Phi_{\mathrm{DRF}}$ over the CEC region range between $6.9 \%$ (summer) and $47.9 \%$ (winter) and between $6.7 \%$ (summer) and $47.5 \%$ (winter), respectively, showing annual average contributions of $23.3 \%$ and $22.8 \%$. However, these contributions $\left(\Phi_{\mathrm{AOD}}\right.$ and $\left.\Phi_{\mathrm{DRF}}\right)$ decrease over the regions surrounding China: the Korean Peninsula (19.4\% and $19.6 \%)$, Japan $(10.7 \%$ and $10.9 \%)$, and Taiwan (5.4\% and $5.5 \%)$, as shown in Table 2 . Under all-sky conditions, the annual average values of $\Phi_{\mathrm{DRF}}$ were found to be $21.0 \%$ over the CEC region, $15.6 \%$ over the Korean Peninsula, $8.5 \%$ over Japan, and $3.1 \%$ over Taiwan. Based on this analysis, it can be said that $\Phi_{\mathrm{AOD}}$ and $\Phi_{\mathrm{DRF}}$ over East Asia are so large, particularly during the winter season, that they cannot (should not) be ignored in the East Asian air quality and radiative forcing studies.

The contributions of $\mathrm{NH}_{4} \mathrm{NO}_{3}$ to AOD and DRF by aerosols over East Asia were estimated and were then compared with the contributions of other particulate species such as $\left(\mathrm{NH}_{4}\right)_{2} \mathrm{SO}_{4}$, mineral dust, $\mathrm{BC}$, organic aerosols (OAs), and sea-salt particles in Fig. 16. As shown in Fig. 16, the 
Table 2. The contribution of ammonium nitrate to AODs and DRFs ( $\Phi_{\text {AOD }}^{\mathrm{c}}$ and $\Phi_{\mathrm{DRF}}^{\mathrm{d}}$ ) at AERONET sites and over East Asia, China $(\mathrm{CEC})$, Korea, Japan, and Taiwan under clear-sky and all-sky conditions.

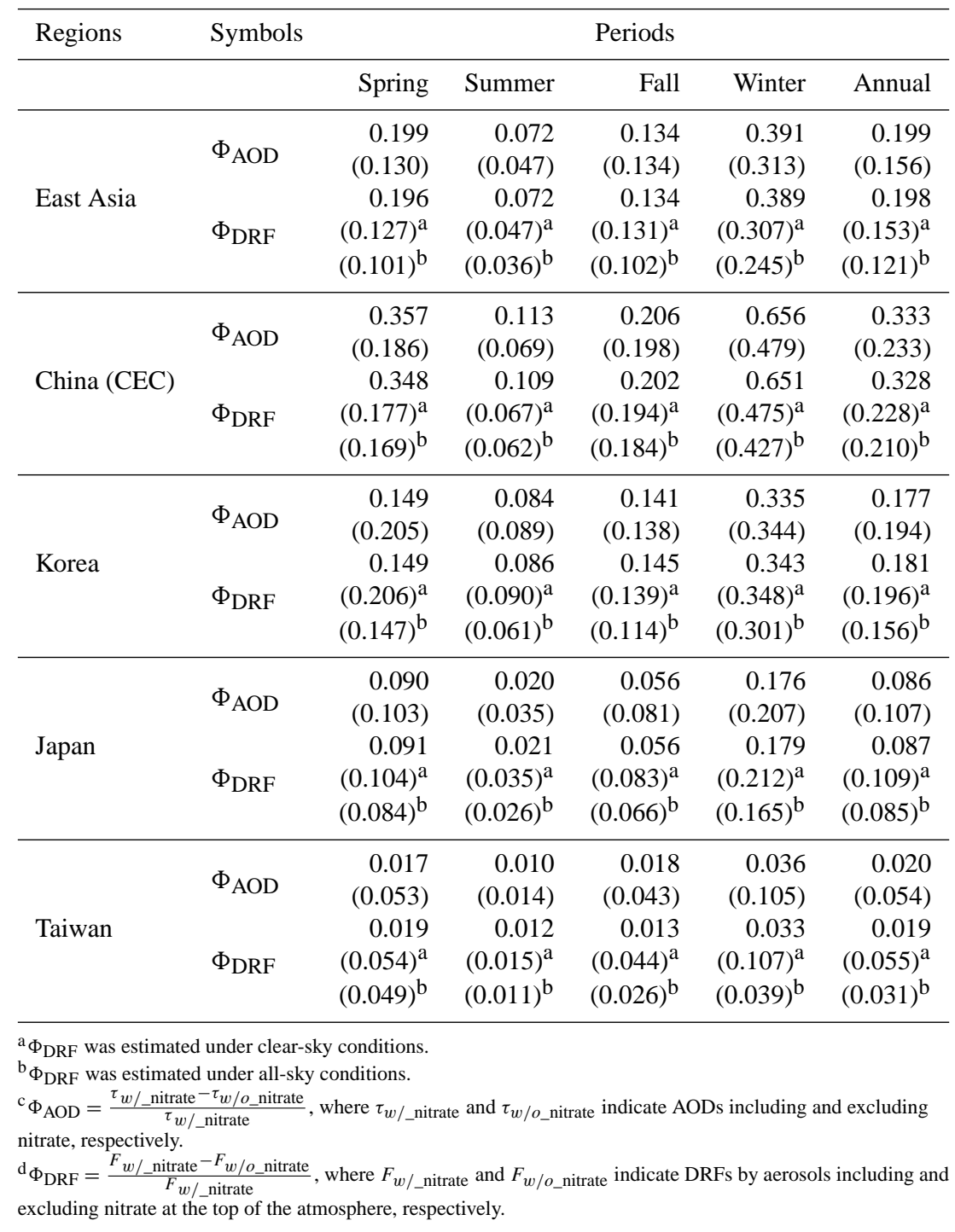

largest contributor to AOD and DRF by aerosols (in terms of TOA and surface forcing) is $\left(\mathrm{NH}_{4}\right)_{2} \mathrm{SO}_{4}$ in East Asia, and the second largest contributor is $\mathrm{NH}_{4} \mathrm{NO}_{3}$. The contribution of $\mathrm{NH}_{4} \mathrm{NO}_{3}$ to DRF by aerosols at the surface (i.e., surface forcing) was almost comparable to that of $\mathrm{BC}$. These results again support that the contributions of $\mathrm{NH}_{4} \mathrm{NO}_{3}$ to AOD and DRF by aerosols should not be neglected in East Asia.

\section{Conclusions and outlook}

In this study, the contribution of $\mathrm{NH}_{4} \mathrm{NO}_{3}$ to $\mathrm{AOD}$ and DRF by aerosols $\left(\Phi_{\mathrm{AOD}}\right.$ and $\left.\Phi_{\mathrm{DRF}}\right)$ over East Asia was investigated. In order to evaluate the accuracy of CMAQcalculated particulate concentrations, the CMAQ-calculated particulate concentrations were compared with those from the EANET and CAWNET. Although some errors and biases between the two particulate concentrations were found, relatively good agreements are shown between the two data sets. For improvement of the accuracy of the AOD data, CMAQ-calculated AOD was assimilated, using MODISderived AOD, over East Asia for the entire year of 2006. After the assimilation, seasonally varying DRF by aerosols over East Asia was estimated using the assimilated and modelcalculated aerosol optical properties via a radiative transfer model, SBDART. The assimilated AOD and estimated DRF by aerosols showed good agreements with the AOD and DRF by aerosols from AERONET. Based on these results, both $\Phi_{\mathrm{AOD}}$ and $\Phi_{\mathrm{DRF}}$ were estimated over East Asia for the four seasons in 2006 under clear-sky and all-sky conditions. It was found from the analysis that $\Phi_{\mathrm{AOD}}$ and $\Phi_{\mathrm{DRF}}$ are large during 
the cold months. Both $\Phi_{\mathrm{AOD}}$ and $\Phi_{\mathrm{DRF}}$ vary seasonally with ranges between $4.7 \%$ (summer) and $31.3 \%$ (winter) and between $4.7 \%$ (summer) and $30.7 \%$ (winter) over East Asia under clear-sky conditions, respectively. Under all-sky conditions, $\Phi_{\mathrm{DRF}}$ varied between $3.6 \%$ (summer) and $24.5 \%$ (winter), showing annual average contribution of $12.1 \%$ over East Asia. However, these $\Phi_{\mathrm{AOD}}$ and $\Phi_{\mathrm{DRF}}$ become even larger in the locations where $\mathrm{NH}_{3}$ and $\mathrm{NO}_{\mathrm{x}}$ emission rates are strong, such as in central East China and Sichuan regions. For example, under clear-sky conditions, $\Phi_{\mathrm{DRF}}$ changes by between $10.9 \%$ (summer) and $65.1 \%$ (winter) at the two Chinese AERONET sites near Beijing. Based on this analysis, it can be said that $\Phi_{\mathrm{AOD}}$ and $\Phi_{\mathrm{DRF}}$ over East Asia are so large, particularly during the winter season, that they cannot be ignored in the East Asian air quality and radiative forcing studies. Based on the analysis of DRF by particulate species, the contribution of $\mathrm{NH}_{4} \mathrm{NO}_{3}$ to DRF by aerosols at the surface (i.e., surface forcing) was almost comparable to that of BC.

Furthermore, recent studies have reported that the global contributions of $\mathrm{NH}_{4} \mathrm{NO}_{3}$ to AOD and DRF by aerosols are expected to become comparable to those of $\left(\mathrm{NH}_{4}\right)_{2} \mathrm{SO}_{4}$ in the near future, since the atmospheric burden of $\mathrm{NH}_{4} \mathrm{NO}_{3}$ is increasing; however, the burden of $\left(\mathrm{NH}_{4}\right)_{2} \mathrm{SO}_{4}$ is decreasing continuously (Nakicenovic et al., 2000; Bauer et al., 2007; Bellouin et al., 2011). This is particularly true for East Asia. Therefore, it is necessary for us to continue monitoring the contributions of $\mathrm{NH}_{4} \mathrm{NO}_{3}$ to AOD and DRF by aerosols over East Asia.

\section{Supplementary material related to this article is available online at http://www.atmos-chem-phys.net/14/ 2185/2014/acp-14-2185-2014-supplement.pdf.}

Acknowledgements. This research was supported by Ministry of Environment, Republic of Korea, as a part of the "Eco-Innovation project" (411-113-013) in Korea; by the GEMS program of the Ministry of Environment, Republic of Korea, as part of the Eco Innovation Program of KEITI (2012000160004), by the Korea Meteorological Administration Research and Development Program under grant CATER 2012-7110, and by the "Basic Research Projects in High-tech Industrial Technology" project through a grant provided by GIST in 2013. In this study, MODIS-retrieved aerosol data were obtained from http://ladsweb.nascom.nasa.gov/data/search.html.

Edited by: K. Schaefer

\section{References}

Adams, P. J., Seinfeld, J. H., and Koch, D. M.: Global concentration of tropospheric sulfate, nitrate, and ammonium aerosol simulated in a general circulation model, J. Geophys. Res., 104, 13791$13823,1999$.

Andreae, M. O.: Climatic effects of changing atmospheric aerosol levels in World Survey of Climatology: Future Climates of the World, vol. 16, edited by: Henderson-Sellers, A., 341-392, Elsevier, Amsterdam, 1995.

Bauer, S. E., Koch, D., Unger, N., Metzger, S. M., Shindell, D. T., and Streets, D. G.: Nitrate aerosols today and in 2030: a global simulation including aerosols and tropospheric ozone, Atmos. Chem. Phys., 7, 5043-5059, doi:10.5194/acp-7-5043-2007, 2007.

Bellouin, N., Rae, J., Jones, A., Johnson, C., Haywood, J., and Boucher, O.: Aerosol forcing in the Climate Model Intercomparison Project (CMIP5) simulations by HadGEM2-ES and the role of ammonium nitrate, J. Geophys. Res., 116, D20206, doi:10.1029/2011JD016074, 2011.

Carlton, A. G., Wiedinmyer, C., and Kroll, J. H.: A review of Secondary Organic Aerosol (SOA) formation from isoprene, Atmos. Chem. Phys., 9, 4987-5005, doi:10.5194/acp-9-4987-2009, 2009.

Carter, W. P. L.: Implementation of the SAPRC-99 Chemical Mechanism into the Models-3 Framework. Report to the United States Environmental Protection Agency, available at: http://www. cert.ucr.edu/ carter/pubs/s99mod3.pdf (last access: 19 February 2014), 2000.

Chin, M., Ginoux, P., Kinne, S., Torres, O., Holben, B. N., Duncan, B. N., Martin, R. V., Logan, J. A., Higurashi, A., and Nakajima, T.: Tropospheric Aerosol Optical Thickness from the GOCART Model and Comparisons with Satellite and Sun Photometer Measurements, J. Atmos. Sci., 59, 461-483, 2001.

Choi, Y.-S., Park, R. J., and Ho, C.-H. : Estimates of ground-level aerosol mass concentrations using a chemical transport model with Moderate Resolution Imaging Spectroradiometer (MODIS) aerosol observations over East Asia, J. Geophys. Res., 114, D04204, doi:10.1029/2008JD011041, 2009.

Chung, C. E., Ramanathan, V., Kim, D., and Podgorny, I.: Global anthropogenic aerosol direct radiative forcing derived from satellite and ground-based observations, J. Geophys. Res., 110, D24207, doi:10.1029/2005JD006356, 2005.

Chung, C. E., Ramanathan, V., Carmichael, G., Kulkarni, S., Tang, Y., Adhikary, B., Leung, L. R., and Qian, Y.: Anthropogenic aerosol radiative forcing in Asia derived from regional models with atmospheric and aerosol data assimilation, Atmos. Chem. Phys., 10, 6007-6024, doi:10.5194/acp-10-6007-2010, 2010.

Conant, W. C., Seinfeld, J. H., Wang, J., Carmichael, G. R., Tang, Y., Uno, I., Flatau, P. J., Markowicz, K. M., and Quinn, P. K.: A model for the radiative forcing during ACE-Asia derived from CIRPAS Twin Otter and R/V Ronald H. Brown data and comparison with observations, J. Geophys. Res., 108, 8661, doi:10.1029/2002JD003260, 2003.

Dubuisson, P., Buriez, J. C., and Fouquart, Y.: High spectral resolution solar radiative transfer in absorbing and scattering media: Application to the satellite simulation, J. Quant. Spectrosc. Ra., 55, 103-126, 1996.

Dubovik, O., Smirnov, A., Holben, B. N., King, M. D., Kaufman, Y. J., Eck, T. F., and Slutsker, I.: Accuracy assessments of 
aerosol optical properties retrieved from Aerosol Robotic Network (AERONET) Sun and sky radiance measurements, J. Geophys. Res., 105, 9791-9806, doi:10.1029/2000JD900040, 2000.

Fountoukis, C. and Nenes, A.: ISORROPIA II: a computationally efficient thermodynamic equilibrium model for $\mathrm{K}^{+}, \mathrm{Ca}^{2+}$, $\mathrm{Mg}^{2+}, \mathrm{NH}_{4}^{+}, \mathrm{Na}^{+}, \mathrm{SO}_{4}^{2-}, \mathrm{NO}_{3}^{-}, \mathrm{Cl}^{-}, \mathrm{H}_{2} \mathrm{O}$ aerosols, Atmos. Chem. Phys., 7, 4639-4659, doi:10.5194/acp-7-4639-2007, 2007.

Garcia, O. E., Diaz, A. M., Exposito, F. J., Diaz, J. P., Dubovik, O., Dubuisson, P., Roger, J.-C., Eck, T. F., Sinyuk, A., Derimian, Y., Dutton, E. G., Schafer, J. S., Holben, B., and Garcia, C. A.: Validation of AERONET estimates of atmospheric solar fluxes and aerosol radiative forcing by groundbased broadband measurements, J. Geophys. Res., 113, D21207, doi:10.1029/2008JD010211, 2008.

García, O. E., Díaz, J. P., Expósito, F. J., Díaz, A. M., Dubovik, O., Derimian, Y., Dubuisson, P., and Roger, J.-C.: Shortwave radiative forcing and efficiency of key aerosol types using AERONET data, Atmos. Chem. Phys., 12, 5129-5145, doi:10.5194/acp-125129-2012, 2012.

Ge, J. M., Su, J., Ackerman, T. P., Fu, Q., Huang, J. P., and Shi, J. S.: Dust aerosol optical properties retrieval and radiative forcing over northwestern China during the 2008 ChinaU.S. joint field experiment, J. Geophys. Res., 115, D00K12, doi:10.1029/2009JD013263, 2010.

Han, K. M., Song, C. H., Ahn, H. J., Park, R. S., Woo, J. H., Lee, C. K., Richter, A., Burrows, J. P., Kim, J. Y., and Hong, J. $\mathrm{H}$.: Investigation of $\mathrm{NOx}$ emissions and $\mathrm{NO}_{\mathrm{X}}$-related chemistry in East Asia using CMAQ-predicted and GOME-derived $\mathrm{NO}_{2}$ columns, Atmos. Chem. Phys., 9, 1017-1036, doi:10.5194/acp9-1017-2009, 2009.

Holben, B. N., Eck, T. F., Slutsker, I., Tanré, D., Buis, J. P., Setzer, A., Vermote, E., Reagan, J. A., Kaufman, Y. J., Nakajima, T., Lavenu, F., Jankowiak, I., and Smirnov, A.: AERONET - A Federated Instrument Network and Data Archive for Aerosol Characterization, Remote Sens. Environ., 66, 1-16, 1998.

Jacobson, M. Z.: Global direct radiative forcing due to multicomponent anthropogenic and natural aerosols, J. Geophys. Res., 106, 1551-1568, doi:10.1029/2000JD900514, 2001.

Jeong, J. I., Park, R. J., Woo, J.-H., Han, Y.-J., and Yi, S.-M.: Source contributions to carbonaceous aerosol concentrations in Korea, Atmos. Environ., 45, 1116-1125, 2011.

Kim, J. Y., Song, C. H., Ghim, Y. S., Won, J. G., Yoon, S. C., Carmichael, G. R., and Woo, J.-H.: An investigation on $\mathrm{NH}_{3}$ emissions and particulate $\mathrm{NH}_{4}^{+}-\mathrm{NO}_{3}^{-}$formation in East Asia, Atmos. Environ., 40, 2139-2150, 2006.

Kim, M. Y., Lee, S. B., Bae, G. N., Park, S. S., Han, K. M., Park, R. S., Song, C. H., and Park, S. H.: Distribution and direct radiative forcing of black carbon aerosols over Korean Peninsula, Atmos. Environ., 58, 45-55, 2012.

Kinne, S., Lohmann, U., Feichter, J., Schulz, M., Timmreck, C., Ghan, S., Easter, R., Chin, M., Ginoux, P., Takemura, T., Tegen, I., Koch, D., Herzog, M., Penner, J., Pitari, G., Holben, B., Eck, T., Smirnov, A., Dubovik, O., Slutsker, I., Tanre, D., Torres, O., Mishchenko, M., Geogdzhayev, I., Chu, D. A., and Kaufman, Y.: Monthly averages of aerosol properties: A global comparison among models, satellite data, and AERONET ground data, J. Geophys. Res., 108, 4634, doi:10.1029/2001JD001253, 2003.
Koch, D., Jacob, D. J., Tegen, I., Rind, D., and Chin, M.: Tropospheric sulfur simulation and sulfate direct radiative forcing in the Goddard Institute for Space Studies general circulation model, J. Geophys. Res., 104, 23799-23822, 1999.

Lin, L., Fu, Q., Zhang, H., Su, J., Yang, Q., and Sun, Z.: Upward mass fluxes in tropical upper troposphere and lower stratosphere derived from radiative transfer calculations, J. Quant. Spectrosc. Ra., 117, 114-122, 2013.

Luo, C., Wang, Y., Mueller, S., and Knipping, E.: Diagnosis of an underestimation of summertime sulfate using the Community Multiscale Air Quality model, Atmos. Environ., 45, 5119-5130, 2011.

Lu, Z., Streets, D. G., Zhang, Q., Wang, S., Carmichael, G. R., Cheng, Y. F., Wei, C., Chin, M., Diehl, T., and Tan, Q.: Sulfur dioxide emissions in China and sulfur trends in East Asia since 2000, Atmos. Chem. Phys., 10, 6311-6331, doi:10.5194/acp-106311-2010, 2010.

Matsui, H., Koike, M., Takegawa, N., Kondo, Y., Griffin, R. J., Miyazaki, Y., Yokouchi, Y., and Ohara, T.: Secondary organic aerosol formation in urban air: Temporal variations and possible contributions from unidentified hydrocarbons, J. Geophys. Res., 114, D04201, doi:10.1029/2008JD010164, 2009.

Mi, W., Li, Z., Xia, X., Holben, B., Levy, R., Zhao, F., Chen, H., and Cribb, M.: Evaluation of the Moderate Resolution Imaging Spectroradiometer aerosol products at two Aerosol Robotic Network stations in China, J. Geophys. Res., 112, D22S08, doi:10.1029/2007JD008474, 2007.

Nakicenovic, N., Davidson, O., Davis, G., Grübler, A., Kram, T., Lebre La Rovere, E., Metz, B., Morita, T., Pepper, W., Pitcher, H., Sankovski, A., Shukla, P., Swart, R., Watson, R., and Dadi, Z. (Eds.) : Emissions Scenarios - Summary for Policymakers. A Special Report of Working Group of the Intergovernmental Panel on Climate Change (IPCC), 20 pp., IPCC, Geneva, Switzerland, 2000.

Nenes, A., Pandis, S. N., and Pilinis, C.: ISORROPIA: a new thermodynamic equilibrium model for multiphase multi-component inorganic aerosols, Aquat. Geochem., 4, 123-152, 1998.

Park, R. S., Cho., Y.-K., Choi, B.-J., and Song, C. H.: Implications of sea surface temperature deviations in the prediction of wind and precipitable water over the Yellow Sea, J. Geophys. Res., 116, D17106, doi:10.1029/2011JD016191, 2011 a.

Park, R. S., Song, C. H., Han, K. M., Park, M. E., Lee, S.-S., Kim, S.-B., and Shimizu, A.: A study on the aerosol optical properties over East Asia using a combination of CMAQ-simulated aerosol optical properties and remote-sensing data via a data assimilation technique, Atmos. Chem. Phys., 11, 12275-12296, doi:10.5194/acp-11-12275-2011, 2011 b.

Pleim, J. E., Clarke, J. E., Finkelstein, P. L., Cooter, E. J., Ellestad, T. G., Xiu, A., and Angevine, W. M.: Comparison of measured and modeled surface fluxes of heat, moisture and chemical dry deposition, in: Air Pollution Modeling and Its Application XI, edited by: Gryning, S.-E. and Schiermeier, F. A., Plenum Press, New York, 1996.

Qianshan, H., Chengcai, L., Xu, T., Huiling, L., Fuhai, Geng., and Yongli, W.: Validation of MODIS derived aerosol optical depth over the Yangtze River Delta, Remote Sens. Environ., 114, 16491661, 2010.

Ramanathan, V., Crutzen, P. J., Lelieveld, J., Mitra, A. P., Althausen, D., Anderson, J., Andreae, M. O., Cantrell, W., Cass, G. R., 
Chung, C. E., Clarke, A. D., Coakley, J. A., Collins, W. D., Conant, W. C., Dulac, F., Heintzenberg, J., Heymsfield, A. J., Holben, B., Howell, S., Hudson, J., Jayaraman, A., Kiehl, J. T., Krishnamurti, T. N., Lubin, D., McFarquhar, G., Novakov, T., Ogren, J. A., Podgorny, I. A., Prather, K., Priestley, K., Prospero, J. M., Quinn, P. K., Rajeev, K., Rasch, P., Rupert, S., Sadourny, R., Satheesh, S. K., Shaw, G. E., Sheridan, P., and Valero, F. P. J.: Indian Ocean Experiment: An integrated analysis of the climate forcing and effects of the great Indo-Asian haze, J. Geophys. Res., 106, 28371-28399, 2001.

Ricchiazzi, P., Yang, S., Gautier, C., and Sowle, D.: SBDART: a research and teaching software tool for plane-parallel radiative transfer in the Earth's atmosphere, B. Am. Meteorol. Soc., 79, 2101-2114, 1998.

Roger, J.-C., Mallet, M., Dubuisson, P., Cachier, H., Vermote, E., Dubovik, O., and Despiau, S.: A synergetic approach for estimating the local direct aerosol forcing: Applications to an urban zone during the Expérience sur Site pour Contraindre les Modèles de Pollution et de Transport d'Emission (DSCOMPTE) experiment, J. Geophys. Res., 111, D13208, doi:10.1029/2005JD006361, 2006.

Scott, N. A.: A direct method of computation of the transmission function of an inhomogeneous gaseous medium-I: Description of the method, J. Quant. Spectrosc. Ra., 14, 691-704, 1974.

Seinfeld, J. H., Carmichael, G. R., Arimoto, R., Conant, W. C., Brechtel, F. J., Bates, T. S., Cahill, T. A., Clarke, A. D., Flatau, P., J., Huebert, B. J., Kim, J., Markowicz, K. M., Quinn, P. K., Rusell, L. M., Rusell, P. B., Shimizu, A., Shinozuka, A., Song, C. H., and Tang, Y.: ACE-ASIA: Regional climate and atmospheric chemical effects of Asian dust and pollution, B. Am. Meteorol. Soc., 85, 367-380, 2004.

Sena, E. T., Artaxo, P., and Correia, A. L.: Spatial variability of the direct radiative forcing of biomass burning aerosols and the effects of land use change in Amazonia, Atmos. Chem. Phys., 13, 1261-1275, doi:10.5194/acp-13-1261-2013, 2013.

Smith, S. J., van Aardenne, J., Klimont, Z., Andres, R. J., Volke, A., and Delgado Arias, S.: Anthropogenic sulfur dioxide emissions: 1850-2005, Atmos. Chem. Phys., 11, 1101-1116, doi:10.5194/acp-11-1101-2011, 2011.

Song, C. H., Chen, G., and Davis, D. D.: Chemical evolution and dispersion of ship plumes in the remote marine boundary layer: investigation of sulfur chemistry, Atmos. Environ., 37, 26632679, 2003.

Song, C. H., Maxwell-Meier, K., Weber, R. J., Kapustin, V., and Clarke, A.: Dust composition and mixing state inferred from airborne composition measurements during ACE-Asia C130 Flight\#6, Atmos. Environ., 39, 359-369, 2005.

Song, C. H., Kim, C. M., Lee, Y. J., Carmichael, G. R., Lee, B. K., and Lee, D. S.: An evaluation of reaction probabilities of sulfate and nitrate precursors onto East Asian dust particles, J. Geophys. Res., 112, D18206, doi:10.1029/2006JD008092, 2007a.

Song, C. H., Han, K. M., Cho, H. J., Kim, J., Carmichael, G. R., Thongboonchoo, N., Kurata, G., He, Z., and Kim, H. S.: A Lagrangian model investigation of chemico-microphysical evolution of northeast Asian pollution plumes within the MBL during TRACE-P, Atmos. Environ. , 41, 8932-8951, 2007b.

Song, C. H., Park, M. E., Lee, K. H., Ahn, H. J., Lee, Y., Kim, J. Y., Han, K. M., Kim, J., Ghim, Y. S., and Kim, Y. J.: An investigation into seasonal and regional aerosol characteristics in East Asia us- ing model-predicted and remotely-sensed aerosol properties, Atmos. Chem. Phys., 8, 6627-6654, doi:10.5194/acp-8-6627-2008, 2008.

Song, C. H., Nam, J. E., Han, K. M., Lee, M. K., Woo, J. H., and Han, J. S.: Influence of mineral dust mixingstate and reaction probabilities on size-resolved sulfate formation in Northeast Asia, Atmos. Environ., 58, 23-34, doi:10.1016/j.atmosenv.2011.10.057, 2012.

Takemura, T., Nakajima, T., Dubovik, O., Holben, B. N., and Kinne, S.: Single-scattering albedo and radiative forcing of various aerosol species with a global three-dimensional model, J. Climate, 15, 333-352, 2002.

US Committee on Extension to the Standard Atmosphere: U.S. Standard Atmosphere, US Government Printing Office, Washington, D.C., 1962.

Valenzuela, A., Olmo, F. J., Lyamani, H., Antón, M., Quirantes, A., and Alados-Arboledas, L.: Aerosol radiative forcing during African desert dust events (2005-2010) over Southeastern Spain, Atmos. Chem. Phys., 12, 10331-10351, doi:10.5194/acp12-10331-2012, 2012.

van Dorland, R., Dentener, F. J., and Lelieveld, J.: Radiative forcing due to tropospheric ozone and sulfate aerosols, J. Geophys. Res., 102, 28079-28100, 1997.

Volkamer, R., Jimenez, J. L., San Martini, F., Dzepina, K., Zhang, Q., Salcedo, D., Molina, L. T., Worsnop, D. R., and Molina, M. J.: Secondary organic aerosol formation from anthropogenic air pollution: Rapid and higher than expected, Geophys. Res. Lett., 33, L17811, doi:10.1029/2006GL026899, 2006.

Wang, L., Xin, J., Wang, Y., Li, Z., Liu, G., and Li, J.: Evaluation of the MODIS aerosol optical depth retrieval over different ecosystems in China during EAST-AIRE, Atmos. Environ., 41, 71387149, 2007.

Wang, Z., Akimoto, H., and Uno, I.: Neutralization of soil aerosol and its impact on the distribution of acid rain over East Asia: Observations and model results, J. Geophys. Res., 107, 4389, doi:10.1029/2001JD001040, 2002.

Xia, X. and Zong, X.: Shortwave versus longwave direct radiative forcing by Taklimakan dust aerosols, Geophys. Res. Lett., 36, L07803, doi:10.1029/2009GL037237, 2009.

Xie, Y., Zhang, Y., Xiong, X., Qu, J. J., and Che, H.: Valication of MODIS aerosol optical deth over China using CARSNET measurements, Atmos. Environ., 45, 5970-5978, 2011.

Zhang, H., Wang, Z., Wang, Z., Liu, Q., Gong, S., Zhang, Z., Shen, Z., Lu, P., Wei, X., Che, H., and Li, L.: Simulation of direct radiative forcing of aerosols and their effects on East Asian climate using an interactive AGCM-aerosol coupled system, Clim. Dynam., 38, 1675-1693, 2012a.

Zhang, X. Y., Wang, Y. Q., Niu, T., Zhang, X. C., Gong, S. L., Zhang, Y. M., and Sun, J. Y.: Atmospheric aerosol compositions in China: spatial/temporal variability, chemical signature, regional haze distribution and comparisons with global aerosols, Atmos. Chem. Phys., 12, 779-799, doi:10.5194/acp12-779-2012, 2012b.

Zhang, Y., Liu, P., Queen, A., Misenis, C., Pun, B., Seigneur, C., and Wu, S.-Y.: A comprehensive performance evaluation of MM5CMAQ for the Summer 1999 Southern Oxidants Study episode Part II: Gas and aerosol predictions, Atmos. Environ., 40, 48394855, 2006. 
Zheng, J. Y., Yin, S. S., Kang, D. W., Che, W. W., and Zhong, L. J.: Development and uncertainty analysis of a high-resolution $\mathrm{NH}_{3}$ emissions inventory and its implications with precipitation over the Pearl River Delta region, China, Atmos. Chem. Phys., 12, 7041-7058, doi:10.5194/acp-12-7041-2012, 2012.
Zheng, M., Cass, G. R., Schauer, J. J., and Edgerton, E. S.: Source apportionment of $\mathrm{PM}_{2.5}$ in the Southeastern United States using solvent-Extractable organic compounds as tracers, Environ. Sci. Technol., 36, 2361-2371, 2002. 